\title{
Observations of total peroxy nitrates and aldehydes: measurement interpretation and inference of $\mathrm{OH}$ radical concentrations
}

\author{
P. A. Cleary ${ }^{1, *}$, P. J. Wooldridge ${ }^{1}$, D. B. Millet ${ }^{2, * *}$, M. McKay ${ }^{2}$, A. H. Goldstein ${ }^{2,4}$, and R. C. Cohen ${ }^{1,3,4}$ \\ ${ }^{1}$ Department of Chemistry, University of California, Berkeley, Berkeley, CA 94720, USA \\ ${ }^{2}$ Department of Environmental Science, Policy and Management, University of California, Berkeley, Berkeley, CA 94720, \\ USA \\ ${ }^{3}$ Department of Earth and Planetary Science, University of California, Berkeley, Berkeley, CA 94720, USA \\ ${ }^{4}$ Environment Technologies Division, Lawrence Berkeley National Laboratory, Berkeley, CA 94720, USA \\ *now at: Department of Chemistry, University of Pennsylvania, 231 S. 34th St, Philadelphia, PA 19104, USA \\ ** now at: Department of Earth and Planetary Sciences, Harvard University, Cambridge, MA 02138, USA
}

Received: 30 October 2006 - Published in Atmos. Chem. Phys. Discuss.: 12 December 2006

Revised: 19 March 2007 - Accepted: 2 April 2007 - Published: 18 April 2007

\begin{abstract}
We describe measurements of total peroxy nitrates ( $\Sigma \mathrm{PNs}$ ), $\mathrm{NO}_{2}, \mathrm{O}_{3}$ and several aldehydes at Granite Bay, California, during the Chemistry and Transport of the Sacramento Urban Plume-2001 (CATSUP 2001) campaign, from 19 July-16 September 2001. We observed a strong photochemically driven variation of $\Sigma$ PNs during the day with the median of $1.2 \mathrm{ppb}$ at noon. Acetaldehyde, pentanal, hexanal and methacrolein had median abundances in the daytime of $1.2 \mathrm{ppb}, 0.093 \mathrm{ppb}, 0.14 \mathrm{ppb}$, and $0.27 \mathrm{ppb}$, respectively. We compare steady state and time dependent calculations of the dependence of $\Sigma$ PNs on aldehydes, $\mathrm{OH}, \mathrm{NO}$ and $\mathrm{NO}_{2}$ showing that the steady state calculations are accurate to $\pm 30 \%$ between 10:00 and 18:00 h. We use the steady state calculation to investigate the composition of $\Sigma$ PNs and the concentration of $\mathrm{OH}$ at Granite Bay. We find that PN molecules that have never been observed before make up an unreasonably large fraction of the $\Sigma$ PNs unless we assume that there exists a PAN source that is much larger than the acetaldehyde source. We calculate that $\mathrm{OH}$ at the site varied between 2 and $7 \times 10^{6}$ molecule $\mathrm{cm}^{-3}$ at noon during the 8 weeks of the experiment.
\end{abstract}

\section{Introduction}

Peroxyacyl nitrates (or peroxycarboxylic nitric anhydrides) are a class of atmospheric reactive nitrogen $\left(\mathrm{NO}_{\mathrm{y}} \equiv \mathrm{NO}+\right.$ $\mathrm{NO}_{2}+$ peroxy nitrates + alkyl and multifunctional nitrates $+\mathrm{HONO}+\mathrm{HNO}_{3}+\mathrm{NO}_{3}+2 \times \mathrm{N}_{2} \mathrm{O}_{5}$ ) produced by photochemical reactions of aldehydes and photolysis of ketones, such as acetone and methyl glyoxal (Roberts et al., 2002;

Correspondence to: R. C. Cohen

(cohen@cchem.berkeley.edu)
Blitz et al., 2004; Romero et al., 2005). Peroxyacetyl nitrate, PAN, the most abundant and widely studied peroxyacyl nitrate, is produced through the reaction of acetaldehyde with $\mathrm{OH}$, (R1) producing peroxyacyl radical $\left(\mathrm{CH}_{3} \mathrm{C}(\mathrm{O}) \mathrm{O}_{2}\right.$, or PA) followed by the association of PA with $\mathrm{NO}_{2}(\mathrm{R} 2)$. Other sources of PA, such as methyl glyoxal photolysis, may be important, especially where isoprene is the predominant reactive volatile organic compound (VOC) (Roberts et al., 2001). Loss of PAN occurs primarily by the sequential processes of thermal decomposition to regenerate PA $\left(\mathrm{R}_{-2}\right)$ followed by reaction of PA with NO (R3).

$$
\begin{aligned}
& \text { acetaldehyde }+\mathrm{OH}\left(+\mathrm{O}_{2}\right) \rightarrow \mathrm{PA}+\mathrm{H}_{2} \mathrm{O} \\
& \mathrm{PA}+\mathrm{NO}_{2} \rightarrow \text { PAN } \\
& \mathrm{PAN} \rightarrow \mathrm{PA}+\mathrm{NO}_{2} \\
& \mathrm{PA}+\mathrm{NO} \rightarrow \text { products } \\
& \text { PAN }+\mathrm{OH} \rightarrow \text { products }
\end{aligned}
$$

The reaction of PAN with OH (R4) is slow (Talukdar et al., 1995), however this sink of PNs may be important for other PN species, such as MPAN. Figure 1 summarizes the processes represented by R1-R4. The thermal decomposition of PAN (R2-2) has a steep temperature dependence. PAN has a lifetime to thermal decomposition of hours or less in the lower troposphere $(\mathrm{T}>287 \mathrm{~K})$ and of months in the mid- to high latitude free troposphere (Temp $<263 \mathrm{~K}$ ). PAN that is created in situ or transported to the upper troposphere from a source region near the surface can be transported globally (Singh and Hanst, 1981; Beine et al., 1996). When the air containing PAN warms, $\mathrm{NO}_{2}$ is released; thus PAN serves as a vehicle for global scale redistribution of

Published by Copernicus GmbH on behalf of the European Geosciences Union. 


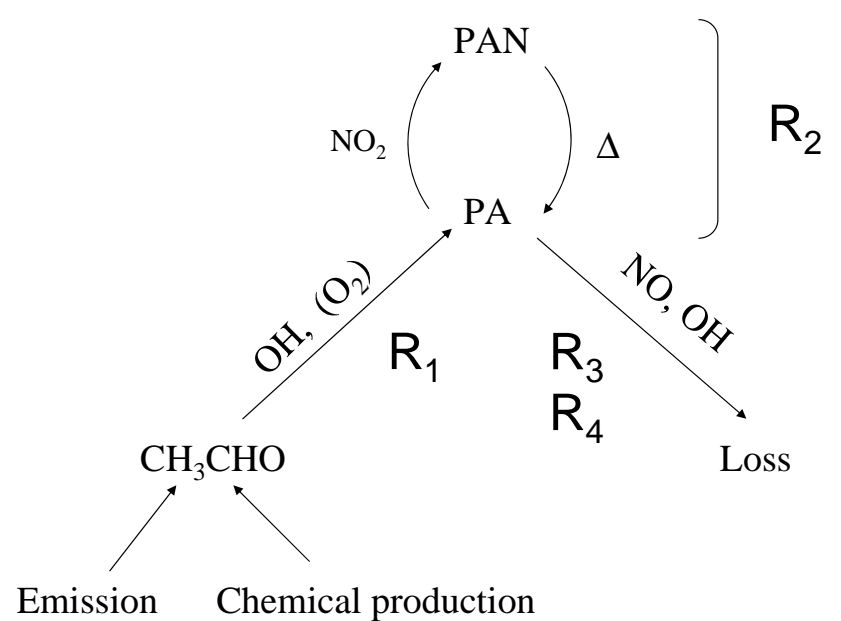

Fig. 1. Diagram of acetaldehyde and PAN photochemistry.

$\mathrm{NO}_{\mathrm{x}}\left(\mathrm{NO}_{\mathrm{x}} \equiv \mathrm{NO}+\mathrm{NO}_{2}\right)$. Peroxyacyl nitrates are also a well known component of urban photochemistry (Stephens et al., 1956; Singh, 1987; Corsmeier et al., 2002b; Rappengluck et al., 2003). PAN is often observed to be correlated with $\mathrm{O}_{3}$ (Penkett and Brice, 1986; Gaffney et al., 1999; Rappengluck et al., 2000; Corsmeier et al., 2002a; Gaffney et al., 2002; Rubio et al., 2004) and the ratios of different PANs have been used to assess the relative contributions of anthropogenic and biogenic sources of $\mathrm{O}_{3}$ (Williams et al., 1997; Roberts et al., 2001). In addition to PAN, other peroxy nitrates are formed following $\mathrm{OH}$-initiated hydrogen abstraction of larger aldehydes. Simultaneous measurements of the ambient concentrations of the aldehyde - peroxyacyl nitrate pairs, propanal-peroxyproprionic nitric anhydride (PPN) (Roberts et al., 2001; Roberts et al., 2003), acrolein-peroxyacrylic nitric anhydride (APAN) (Roberts et al., 2003), and methacrolein-MPAN (Roberts et al., 2001; Roberts et al., 2003) have been described. The peroxyacyl nitrates derived from isobutanal: peroxyisobutyric nitric anhydride (PiBN) (Roberts et al., 2002, 2003), n-butanal: peroxy-n-butyric nitric anhydride (PnBN) (Gaffney et al., 1999; Glavas and Moschonas, 2001) and benzaldehyde: peroxybenzoic nitric anhydride (PBzN) (Atkinson and Lloyd, 1984) have also been identified in the atmosphere. Many other PN compounds have been observed in the laboratory (Wallington et al., 1995; Noziere and Barnes, 1998; Sehested et al., 1998; Tyndall et al., 2001; Hurst-Bowman et al., 2003) and based on these laboratory and field measurements, it is reasonable to assume that virtually every aldehyde observed in the atmosphere should have a corresponding peroxyacyl nitrate. Glavas and Moschonas (2001) have argued that the relative ratios of peroxy nitrates can be deduced from the ratios of parent aldehydes. Roberts et al. $(2001,2003)$ use a sequential reaction model (Reactions 1-4 and their analogues as applied to each PN/aldehyde pair) to explain the correlations between the observed ratios of PPN/propanal,
PAN/acetaldehyde, MPAN/methacrolein and APAN/acrolein (Roberts et al., 2001, 2003). In their analyses, Roberts et al. $(2001,2003)$ attribute the variability PN/aldehyde ratios to plume age and assume that the observations represent oxidation of an isolated plume downwind of a localized source of aldehydes. They show this model does a reasonable job at representing the correlations between different ratios of PN/aldehyde pairs.

In this paper, we describe simultaneous measurements of total peroxy nitrates ( $\Sigma \mathrm{PNs}$ ), aldehydes, $\mathrm{NO}_{2}$ and $\mathrm{O}_{3}$ at the eastern edge of the suburbs of Sacramento, CA as a part of the CATSUP-2001 (Chemistry and Transport of the Sacramento Urban Plume 2001) experiment. We take a different point of view from the papers of Roberts et al. and assume that PNs in the urban boundary layer do not result from emission at a point source but rather are continually affected by emissions of their aldehyde precursors. We compare time dependent and steady state calculations for PNs showing that PNs are in approximate steady state with their source molecules. We then use the steady state calculation to investigate the partitioning of $\Sigma$ PNs among a variety of individual peroxy nitrates and to investigate the concentration of $\mathrm{OH}$ at the Granite Bay site.

\section{Experimental}

Observations of $\mathrm{NO}_{2}, \Sigma$ PNs, total alkyl nitrates ( $\Sigma$ ANs), $\mathrm{HNO}_{3}, \mathrm{O}_{3}$, VOC, and meteorological variables were collected from 19 July-16 September 2001 on the property of Eureka Union School District in Granite Bay, CA (38 $44.23^{\prime} \mathrm{N}, 121^{\circ} 12.01^{\prime} \mathrm{W}, 277 \mathrm{~m}$ above sea level). This site is located $30 \mathrm{~km}$ north-east of Sacramento, CA, at the eastern edge of the suburban region and between two major highways: Interstate $80,8 \mathrm{~km}$ to the north and Highway $50,13 \mathrm{~km}$ to the south. The instruments were housed in a temperaturecontrolled trailer with inlets mounted on a rooftop tower $7 \mathrm{~m}$ above the ground, (1-2 $\mathrm{m}$ above the trailer). The site and instruments are described in detail in Cleary et al. (2005) and only a brief description is included here.

Briefly, wind patterns observed at the site were quite regular, at speeds of $2-2.4 \mathrm{~m} / \mathrm{s}$ from the southwest (directly from Sacramento) during the afternoon (12:00-17:00 h) and from the southeast at $1.6 \mathrm{~m} / \mathrm{s}$ (downslope from the Sierra Nevada) at night (20:00-06:00 h). On most days, the wind direction rotated smoothly and continuously from southeasterlies to southwesterlies between the hours of 06:00-12:00 $\mathrm{h}$ and then rotated back between 17:00 and 20:00 h. On a typical day, the air parcels observed at Granite Bay at noon had arrived at the Sacramento urban core from the South and then turned toward Granite Bay traveling over the entire length of the Sacramento metropolitan region. Temperatures (mean $\pm 1 \sigma)$ at Granite Bay during the campaign were $16( \pm 2.4){ }^{\circ} \mathrm{C}$ at 05:00 h rising to $33( \pm 3.6)^{\circ} \mathrm{C}$ at 16:00 h. Skies were clear on all but two days of the campaign, as determined from 
observations of photosynthetically active radiation. $\mathrm{O}_{3}$ was measured with a Dasibi 1008 ultraviolet photometric ozone analyzer.

$\mathrm{NO}_{2}, \Sigma$ PNs, $\Sigma$ ANs and $\mathrm{HNO}_{3}$ were measured using a two-channel thermal-dissociation laser induced fluorescence (TD-LIF) instrument (Day et al., 2002). Briefly, an ambient sample flows rapidly through two ovens where dissociation of $\mathrm{NO}_{\mathrm{z}}\left(\mathrm{NO}_{z} \equiv \mathrm{HNO}_{3}+\Sigma \mathrm{ANs}+\Sigma \mathrm{PNs}\right)$ species to $\mathrm{NO}_{2}$ occurs. Three different temperatures are used: $180^{\circ} \mathrm{C}$, $350^{\circ} \mathrm{C}$ and $550^{\circ} \mathrm{C}$, to observe the three distinct classes of $\mathrm{NO}_{\mathrm{z}}$ : $\Sigma$ PNs, $\Sigma$ ANs and $\mathrm{HNO}_{3}$. The $\Sigma$ PNs measurement includes PAN, PPN, MPAN, PiBN, PBN and any other peroxy nitrate present in the atmosphere. $\mathrm{N}_{2} \mathrm{O}_{5}$ dissociates at this temperature; however, for the inlet configuration we used at Granite Bay, it is likely $\mathrm{N}_{2} \mathrm{O}_{5}$ was converted to $\mathrm{HNO}_{3}$ on the inlet surfaces prior to the dissociation region. The $\mathrm{NO}_{2}$ signal is the sum of the $\mathrm{NO}_{2}$ contained in all compounds that dissociate at or below the oven temperature, and the difference between the $\mathrm{NO}_{2}$ observed in two separate channels at adjacent temperature set points is associated with a specific class of compounds. For these measurements $\mathrm{NO}_{2}$ was measured using a pulsed dye laser with time gated detection (Thornton et al., 2000). We measured $\mathrm{NO}_{2}, \Sigma \mathrm{PNs}, \Sigma \mathrm{ANs}$, and $\mathrm{HNO}_{3}$ by sequentially adjusting the temperatures of each oven so the pair of ovens remained only one class of $\mathrm{NO}_{\mathrm{y}}$ species apart. The measurements were made on a 4-h repeating cycle. Each time an oven set point was raised, it was pre-programmed to overshoot the set point for a few seconds in order to remove compounds adsorbed to the walls. $\Sigma$ ANs were measured for 75 min each cycle, $\Sigma \mathrm{PNs}$ and $\mathrm{NO}_{2}$ for 40 min each cycle, and $\mathrm{HNO}_{3}$ for $80 \mathrm{~min}$ each cycle, with the remaining time used for measuring zeros, calibrating, and obtaining other diagnostics. During the last six days of the campaign, 11 September-16 September, $\Sigma$ PNs and $\mathrm{NO}_{2}$ were measured continuously.

The accuracy for each class of $\mathrm{NO}_{\mathrm{y}}$ compound is $15 \%$. Comparison of LIF with other $\mathrm{NO}_{2}$ measurements indicates the LIF measurements of $\mathrm{NO}_{2}$ are within $5 \%$ of other $\mathrm{NO}_{2}$ measurements (Thornton et al., 2003). The $\mathrm{NO}_{2}$ signals observed by TD-LIF are adjusted to account for small (5\%) effects of secondary chemistry within our inlet (Rosen et al., 2004). The most important effects are associated with reactions of $\mathrm{RO}_{2}$ (e.g. PA) radicals and $\mathrm{O}_{3}$ with $\mathrm{NO}$. The extent of these interferences depends on the inlet configuration. Over the last few years, we have used 3 different configurations. The configuration used for the Granite Bay experiments was identical to that used in Houston (Rosen, 2004), except that the machined PFA Teflon inlet tip piece was replaced with standard molded fittings for better $\mathrm{HNO}_{3}$ transmission. This inlet was a 2-channel version of the one described in detail by Day et al. (2002). A key feature was the insertion of pressurereducing orifices between the heated tubes and the 15 to $20 \mathrm{~m}$ long PFA Teflon tubes leading to the instrument housed at the base of the tower. Laboratory experiments confirm that interferences in this configuration are small and that our cor- rections accurately accounted for their effects. Comparison of $\Sigma$ PNs to the sum of individual PAN compounds using this inlet and two other inlet configurations during experiments in Houston, TX (Rosen, 2004), from the DC-8 aircraft, from the NCAR C-130 and at a surface site in Nova Scotia have shown that $\Sigma$ PNs are usually within $15 \%$ of the sum of PAN, PPN and MPAN (Wooldridge et al., in preparation). The largest differences we have ever observed, as much as 30\% ( $\Sigma$ PNs $>\Sigma \mathrm{PN}_{i}$ ), were observed when sampling ambient air during the PAN Intercomparison Experiment in Boulder, CO during summer 2005. During this experiment agreement between $\Sigma$ PN and specific PN measurements was within $10 \%$ for test samples of specific compounds including PAN and PPN (Tyndall et al., 2005). However, the poor agreement when sampling ambient air was shown to result from a large interference in the $\Sigma$ PN measurements that was proportional to the product of $\mathrm{NO}$ with $\mathrm{O}_{3}$. Laboratory experiments confirm that the configuration used for the PIE experiments, which omitted the pressure reduction orifices at the back of the heaters in order to keep the pressure at nearly ambient up to the expansion nozzles for the supersonic jets (based on the design outlined by Cleary et al., 2002), resulted in much higher interferences than other configurations because of the longer residence times and higher pressures within $20 \mathrm{~m}$ of tubing connecting the heated inlet and the instrument. The inlet configuration used for the Granite Bay experiments had a more rapid pressure drop and thus has much smaller interferences, ones that we believe are accurately accounted for in the analysis.

Most of the potential systematic error in the individual classes observed by TD-LIF are correlated, in the sense that if $\Sigma$ PNs are too high by $5 \%$ then likely so are $\mathrm{NO}_{2}, \Sigma$ ANs and $\mathrm{HNO}_{3}$. In contrast, ratios of the different classes will be more accurate because these systematic effects will cancel.

We did not measure $\mathrm{NO}$ or $\mathrm{NO}_{y}$ directly. We calculate $\mathrm{NO}$ using the photostationary state equation:

$$
[\mathrm{NO}]_{s s}=\frac{\mathrm{j}_{\mathrm{NO}_{2}}\left[\mathrm{NO}_{2}\right]}{\mathrm{k}_{\mathrm{NO}+\mathrm{O}_{3}}\left[\mathrm{O}_{3}\right]+\mathrm{k}_{\mathrm{HO}_{2}+\mathrm{NO}}\left[\mathrm{HO}_{2}+\mathrm{RO}_{2}\right]}
$$

$\mathrm{HO}_{2}+\mathrm{RO}_{2}$ concentrations are estimated to be $0.020 \mathrm{ppb}$ at noon based on a box model calculation of peroxy-radicals generated from the distribution of 45 VOC measured at Granite Bay (the diurnal profile of these compounds was scaled to PAR). The photolysis rate of $\mathrm{NO}_{2}$ was estimated by scaling the J-values obtained from the TUV model (UCAR, 2002) for 11 August 2001, using total ozone column of 299 DU, as measured by TOMS (McPeters, 2001) to the observed PAR. $\Sigma \mathrm{NO}_{\mathrm{yi}}$ is calculated as the sum of $\mathrm{NO}_{s}$, $\mathrm{NO}_{2}, \Sigma \mathrm{PNs}, \Sigma$ ANs, and $\mathrm{HNO}_{3}$. The largest uncertainty in the $\mathrm{NO}_{s s}$ calculation is due to uncertainties in the calculation of peroxy-radicals. Uncertainties of a factor of two in the peroxy radicals propagate to $15 \%$ uncertainty in $\mathrm{NO}_{s s}$. We conservatively estimate the total uncertainty at $25 \%$. Volatile organic compounds, including aldehydes, were measured hourly with a fully automated, in situ, two-channel 
Table 1. Observed aldehydes at Granite Bay in comparison to those made in Berlin (Grossmann et al., 2003), Nashville (McClenny et al., 1998) and rural Germany (Wedel et al., 1998) given as average concentrations.

\begin{tabular}{lllll}
\hline Aldehyde & $\begin{array}{l}\text { this study } \\
(\mathrm{ppb})\end{array}$ & $\begin{array}{l}\text { Berlin, } \\
\text { Germany }\end{array}$ & $\begin{array}{l}\text { Nashville, } \\
\text { USA }^{2}\end{array}$ & $\begin{array}{l}\text { TN rural, northwestern } \\
\text { Germany }^{3}\end{array}$ \\
\hline Acetaldehyde & 1.20 & 0.30 & & \\
Propanal & $0.14^{*}$ & 0.20 & & \\
Butanal & & 0.10 & 0.40 & \\
Pentanal & 0.093 & 0.10 & 0.22 & 0.011 \\
Hexanal & 0.140 & 0.15 & 0.33 & 0.023 \\
Heptanal & & 0.07 & 0.14 & 0.002 \\
Octanal & & 0.02 & 0.27 & 0.006 \\
Nonanal & & 0.08 & 0.52 & 0.0017 \\
Methacrolein & 0.270 & 0.03 & & \\
\hline
\end{tabular}

* estimated, see section 5 of text. ${ }^{1}$ (Grossmann et al., 2003) ${ }^{2}$ (McClenny et al., 1998) ${ }^{3}$ (Wedel et al., 1998)

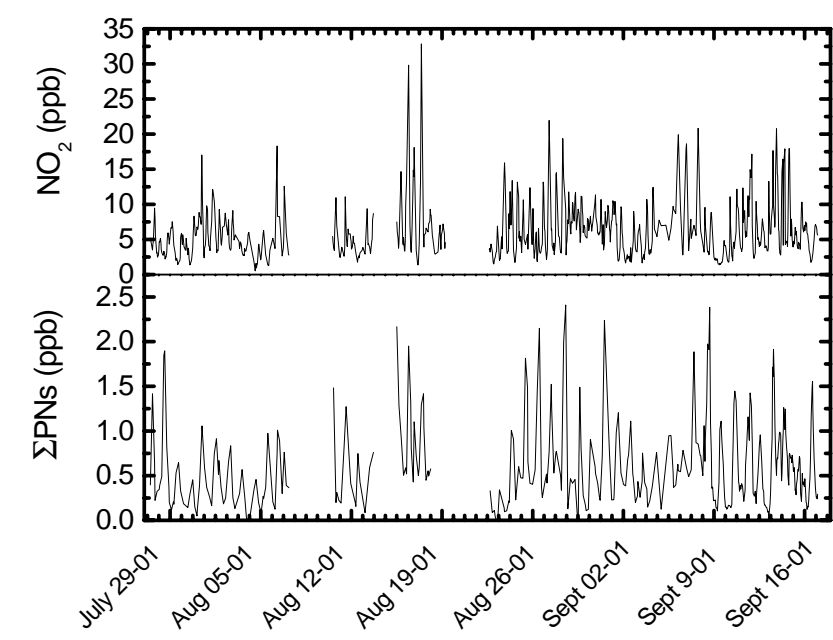

Fig. 2. Measured $\mathrm{NO}_{2}$ and $\Sigma \mathrm{PNs}$ from 27 July through 16 September 2001 . The $10 \mathrm{~s}$ data points were placed into $1-\mathrm{h}$ bins corresponding to the VOC time base and the median of each bin is presented here.

gas chromatograph/mass selective detector/flame ionization detector (GC/MSD/FID) system. This system has been described in detail elsewhere (Millet et al., 2005). Briefly, the FID channel was configured for analysis of $\mathrm{C}_{3}-\mathrm{C}_{6}$ alkanes, alkenes, and alkynes, and the MSD channel for analysis of a range of other VOC, including aromatic, oxygenated and halogenated compounds. For $36 \mathrm{~min}$ out of every hour, two subsample flows $(15 \mathrm{ml} / \mathrm{min})$ were drawn from the main sample line $(4 \mathrm{l} / \mathrm{min})$ and passed through a preconditioning trap for the removal of water $\left(-25^{\circ} \mathrm{C}\right.$ cold trap). Carbon dioxide and ozone were scrubbed from the FID channel subsample (Ascarite II), and ozone was removed from the MSD channel subsample (KI impregnated glass wool). Preconcentration was accomplished using a combination of thermoelectric cooling $\left(-15^{\circ} \mathrm{C}\right)$ and adsorbent trapping. Samples were injected into the GC by rapidly heating the trap assemblies to $200^{\circ} \mathrm{C}$. The instrument was calibrated several times daily by dynamic dilution (factor of 1000) of low ppm level standards (Scott Marin Inc., and Apel-Riemer Environmental Inc.) into zero air. Zero air was analyzed daily to check for blank problems and contamination for all measured compounds. Final data represent samples collected from 15 to $51 \mathrm{~min}$ of each hour (a $36 \mathrm{~min}$ integral).

The $\Sigma \mathrm{PN}$ and $\mathrm{NO}_{2}$ measurements were put on a common time base with the VOC measurements by averaging over the $36 \mathrm{~min}$ of the VOC sampling. Data are included in this analysis if a minimum of $15 \mathrm{~min}$ of $\Sigma \mathrm{PNs}$ and $\mathrm{NO}_{2}$ were obtained during the $36 \mathrm{~min}$ VOC sampling window.

\section{Observations}

Measurements of $\Sigma$ PNs and $\mathrm{NO}_{2}$ from 19 July-16 September 2001 are shown in Fig. 2. $\Sigma$ PNs ranged from 0 to $0.080 \mathrm{ppb}$ at night and had a midday peak that typically occurred between noon and 01:00 p.m. ranging from 0.5$2.5 \mathrm{ppb}$, with a median of $1.2 \mathrm{ppb}$. The average daytime (08:00-20:00 h) mixing ratio of $\Sigma$ PNs was 0.910 ppbv. $\mathrm{NO}_{2}$ peaked during both the morning and evening rush hours with mean concentrations of 8 and $10 \mathrm{ppb}$, respectively. Typical noontime concentrations of $\mathrm{NO}_{2}$ were $4.5 \mathrm{ppb}$. At noon, $\Sigma$ PNs are typically $10 \%$ of $\Sigma \mathrm{NO}_{\mathrm{yi}}$, and they range from 10 $30 \%$ of $\mathrm{NO}_{z}$. These observations of $\Sigma \mathrm{PN}$ mixing ratios are within the typical range of peroxy-nitrates measured at other locations. For example, at the University of California Blodgett Forest Research Center, $5 \mathrm{~h}$ downwind of the Granite Bay site, summertime $\Sigma$ PN measurements peak later in the day (08:00 p.m.) at around $0.550 \mathrm{ppb}$, are $10-20 \%$ of $\Sigma \mathrm{NO}_{\mathrm{yi}}$ and $15-25 \%$ of $\mathrm{NO}_{\mathrm{z}}$ (Day et al., 2003). Roberts et al. (2002) report the sum of 3 PNs: PAN, PPN and MPAN, observed outside of Nashville in June 1999, had an average daytime mixing ratio of $1.14 \mathrm{ppb}\left(10 \%\right.$ of $\left.\mathrm{NO}_{\mathrm{y}}\right)$. At La Porte, Texas 


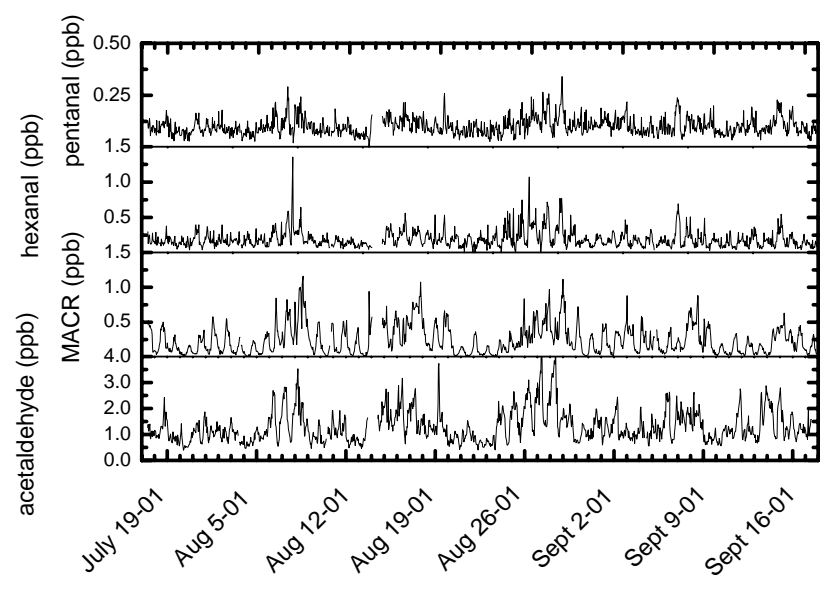

Fig. 3. Hourly measurements of acetaldehyde, methacrolein, pentanal and hexanal from 17 July through 16 September 2001.

during August-September 2000, Roberts et al. (2001) report the sum of 5 different PNs, PAN, PPN, MPAN, PiBN and APAN was on average $1.18 \mathrm{ppb}$, an amount we calculate was $8 \%$ of $\mathrm{NO}_{\mathrm{y}}$ and $17 \%$ of $\mathrm{NO}_{\mathrm{z}}\left(\mathrm{NO}_{\mathrm{y}}-\mathrm{NO}_{\mathrm{x}}\right)$ at that site.

The aldehyde observations are shown in Fig. 3. Acetaldehyde is the most abundant aldehyde, with concentrations ranging 0.5 to $3 \mathrm{ppb}$. Except for methacrolein, the aldehydes reached a maximum at night (when the boundary layer is thinnest) suggesting that in addition to photochemical production, direct emissions and/or $\mathrm{NO}_{3}$ chemistry affect the abundance of aldehydes at this site. Acetaldehyde was generally constant in the morning, and then decreased in the early afternoon, rising in the evening to its nighttime maximum. However, several different daytime patterns were observed as shown in Fig. 4a, which shows acetaldehyde and $\Sigma$ PN observations from 11-16 September 2001. Nearly constant daytime acetaldehyde was observed on 12 and 16 September; a morning increase and afternoon decrease were observed on 13 and 15 September; and a sharp midday decrease was observed on 14 September. On 11 September, the acetaldehyde mixing ratio increased throughout the day. Pentanal and hexanal have similar diurnal patterns to acetaldehyde, although they both show patterns of decreasing midday concentration more frequently than acetaldehyde. Methacrolein generally increased in the morning and peaked in the afternoon, and was strongly correlated to isoprene mixing ratios. Median daytime observations of acetaldehyde, pentanal, hexanal and methacrolein were $1.2 \mathrm{ppb}, 0.093 \mathrm{ppb}, 0.14 \mathrm{ppb}$, and $0.27 \mathrm{ppb}$, respectively.

Our observed mixing ratios of aldehydes are in the range of those reported at two other urban sites, as shown in Table 1. Grossman et al. (2003) measured $\mathrm{C}_{2}-\mathrm{C}_{10}$ aldehydes and methacrolein in July 1998 near Berlin and report the higher n-aldehydes $\left(\mathrm{C}_{7}-\mathrm{C}_{10}\right)$ had a diurnal pattern with maxima at 10:00 a.m. and minima at midnight. McClenny et al. (1998) report n-aldehydes at Nashville are strongly corre-

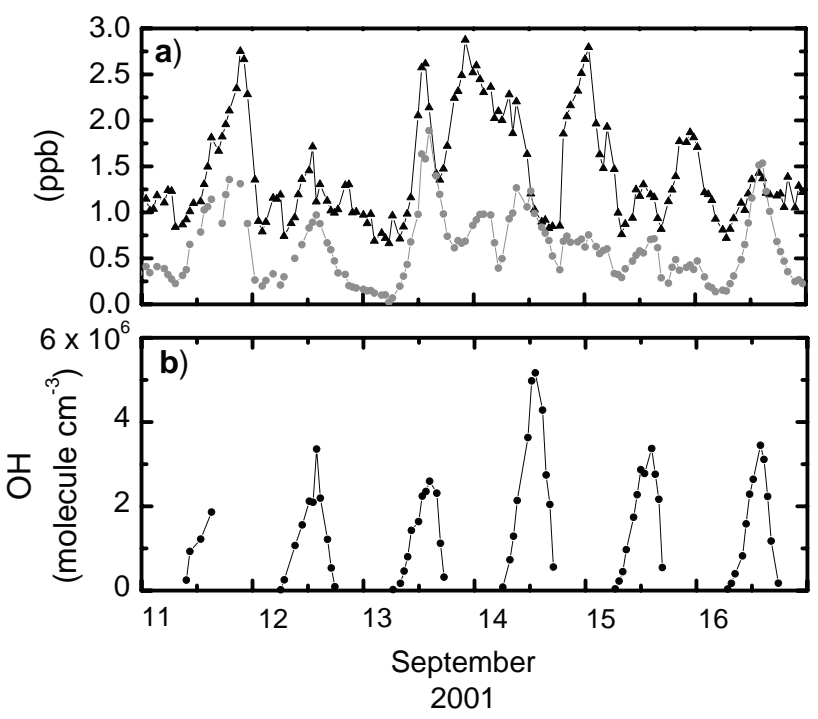

Fig. 4. (a) $\Sigma P N$ (grey circles) and acetaldehyde (black triangles) measurements are plotted, from 11 September-16 September, when continuous measurements of $\Sigma \mathrm{PNs}$ and $\mathrm{NO}_{2}$ were made. (b) Calculated daytime $\mathrm{OH}$ concentrations for the same time period (from M3).

lated with each other, and exhibit a diurnal cycle with minima in the early evening and maxima at noon. Wedel et al. (1998) report $\mathrm{C}_{5}-\mathrm{C}_{9} \mathrm{n}$-aldehydes in rural north-eastern Germany, during August, 1994 and describe night-time maxima in aldehydes. Concentrations of all aldehydes were much lower at this rural site. Grossman et al. (2003) also report that typical maxima were 2-5 times the minima for all aldehydes observed. These observations indicate that the aldehydes we were able to observe are not a complete set. Measurements have shown that there are significant aldehyde emissions from a variety of plant species (Wildt et al., 2003; Vuorinen et al., 2005) and that aldehydes are produced as a result of ozonolysis reactions with fatty acids. Nonanal has received special attention because its production is particularly favorable (Thornberry and Abbatt, 2004; Hung et al., 2005). Ambient mixing ratios for propanal, butanal and hexanal have been reported to be higher than those of pentanal; while mixing ratios of heptanal and octanal are lower than pentanal. Nonanal has been observed at mixing ratios approximately double those of pentanal.

\section{Steady state calculation of peroxy nitrates}

$\Sigma$ PNs, the measurement of total peroxy nitrates, are a new measurement (Day et al., 2002), not previously analyzed in detail. To evaluate the contributions of individual PNs (denoted $\mathrm{PN}_{i}$ ) to $\Sigma \mathrm{PNs}$ we note that when temperatures and $\mathrm{OH}$ concentrations are high, individual PNs are approximately in steady state with their aldehyde sources (R1) and their sink 
Table 2. Important temperature dependent rate coefficients for PAN and products. All rate coefficients from (Atkinson et al., 1997, 2004).

\begin{tabular}{lll}
\hline Reaction & $\mathrm{k}(T)$ or $\mathrm{k}(T,[\mathrm{M}])^{*}$ & $\mathrm{k}(300 \mathrm{~K})$ \\
\hline $\mathrm{PAN} \rightarrow \mathrm{PA}+\mathrm{NO}_{2}$ & $\mathrm{k}_{0}=4.9 \times 10^{-3} \mathrm{~s}^{-1} \exp (-12100 / \mathrm{T})$ & $6.3 \times 10^{-4} \mathrm{~s}^{-1}$ \\
& $\mathrm{k}_{\infty}=5.4 \times 10^{16} \exp (-13830 / \mathrm{T})$ & \\
& $\mathrm{F}_{\text {cent }}=0.3$ & \\
& $\mathrm{~N}=1.41$ & \\
$\mathrm{PA}+\mathrm{NO}_{2} \rightarrow$ PAN & $\mathrm{k}_{0}=2.7 \times 10^{-28}(\mathrm{~T} / 300)^{-7.1}$ & $8.6 \times 10^{-12}$ \\
& $\mathrm{k}_{\infty}=1.2 \times 10^{-11}(\mathrm{~T} / 300)^{-0.9}$ & $\mathrm{~cm}^{3} \mathrm{molec}^{-1} \mathrm{~s}^{-1}$ \\
& $\mathrm{~F}_{\text {cent }}=0.3$ & \\
& $\mathrm{~N}=1$ & \\
$\mathrm{PA}+\mathrm{NO} \rightarrow$ Products & $8.1 \times 10^{-12} \exp (270 / \mathrm{T})$ & $2.0 \times 10^{-11}$ \\
& & $\mathrm{~cm}^{3} \mathrm{molec}^{-1} \mathrm{~s}^{-1}$ \\
\hline
\end{tabular}

$*$ Where $k(M)=\frac{k_{0}[M]}{1+\frac{k_{0}[M]}{k_{\infty}}} * F_{c}$ and $\log F_{c}=\frac{\log F_{\mathrm{cent}}}{1+\left(\frac{\left(\log \frac{k_{0}[M]}{k_{\infty}}\right)}{N}\right)^{2}}$

through the peroxy radical $\left(\mathrm{PA}_{i}\right)+\mathrm{NO}$ reaction $(\mathrm{R} 3)$. $\mathrm{PN}_{i}$ and $\mathrm{PA}_{i}$ are in rapid steady state with a lifetime on the order of minutes for typical surface conditions at Granite Bay in summer, at a daytime mean of $297 \mathrm{~K}$. The steady state condition for the sum of a $\mathrm{PN}_{i}$ and $\mathrm{PA}_{i}$ will be satisfied when the lifetime of $\mathrm{PN}_{T i}\left(\mathrm{PN}_{T i}=\mathrm{PA}_{i}+\mathrm{PN}_{i}\right)$ is of order a few hours or less and the concentration of the aldehyde precursor is nearly constant on that timescale. For example, the lifetime of [PAN+PA] with respect to loss to $\mathrm{R}_{3}$ is on the order of $40 \mathrm{~min}$ at $298 \mathrm{~K}$ using rate coefficients outlined in Table 2 at typical noontime values of $\mathrm{NO}$ and $\mathrm{NO}_{2}$ at Granite Bay. The lifetimes of other PNs are similar or shorter in cases where the reaction with $\mathrm{OH}$ is rapid. Thus, at temperatures greater than $298 \mathrm{~K}$, each $\mathrm{PN}_{i}$ approaches a steady state with its aldehyde source in about an hour. However, the lifetime of acetaldehyde with respect to loss to $\mathrm{OH}$ at noon $\left(298 \mathrm{~K}, \mathrm{OH}=6 \times 10^{6}\right.$ molecule $\left.\mathrm{cm}^{-3}\right)$ is about $3 \mathrm{~h}$. If there were no sources of aldehydes, PNs might not reach a steady state when $\mathrm{OH}$ mixing ratios are at their peak, because of the rapidly decreasing aldehyde concentrations. However, as discussed above, aldehydes exhibit a range of diurnal patterns and the aldehydes are often observed to have nearly constant mixing ratios or to be decreasing more slowly than the lifetime of $3 \mathrm{~h}$ during the day. Thus, $\mathrm{PN}_{T i}$ likely achieves near steady-state conditions.

Steady state equations for $\mathrm{PA}_{i}$ and the $\left(\mathrm{PN}_{T i}\right) /$ aldehyde $_{i}$ ratio derived from Reactions (1)-(4) are:

$$
\begin{aligned}
& {\left[\mathrm{PA}_{i}\right]_{s s}=\frac{\mathrm{k}_{\text {aldehyde }_{\mathrm{i}}}[\mathrm{OH}] *\left[\text { aldehyde }_{\mathrm{i}}\right]+\mathrm{k}_{-2}\left[\mathrm{PN}_{\mathrm{i}}\right]}{\mathrm{k}_{2}\left[\mathrm{NO}_{2}\right]+\mathrm{k}_{3}[\mathrm{NO}]}} \\
& \frac{\left[\mathrm{PN}_{T}\right]_{i}}{[\text { aldehyde }]_{i}}=\frac{\mathrm{k}_{\text {aldehyde }_{\mathrm{i}}} * \beta *[\mathrm{OH}]}{\mathrm{k}_{-2} *(1-\beta)+\mathrm{k}_{4}[\mathrm{OH}]} \\
& \text { where } \beta=\frac{1}{\frac{\mathrm{k}_{3}[\mathrm{NO}]}{\mathrm{k}_{2}\left[\mathrm{NO}_{2}\right]}+1}
\end{aligned}
$$

These equations assume each PN has a single aldehyde source and that the only important sink of PNs is reaction of PA with NO. For the conditions at Granite Bay, we calculate that PA radicals make up less than $1 \%$ of $\mathrm{HO}_{2}+\mathrm{RO}_{2}$ and the loss rate for any peroxy-radical to reaction with $\mathrm{NO}$ is about 300 times faster than peroxy-radical self reactions.

In order to evaluate the accuracy of the steady state approximation represented by Eqs. (2) and (3), we solved the differential equation (Eq. 4) describing PAN mixing ratios over the course of a day by numerical integration:

$$
\begin{aligned}
\frac{d(\mathrm{PAN})}{d(t)}= & \beta(t) * \mathrm{k}_{1}[\operatorname{acetaldehyde}(t)][\mathrm{OH}]-\mathrm{k}_{-2} * \\
& (1-\beta(t)) *[\operatorname{PAN}(t)] .
\end{aligned}
$$

We compare the solution of the time dependent integration (Eq. 4) to the instantaneous steady state (Eq. 3) solution using 4 different scenarios of the production/emission rates for acetaldehyde. We choose four scenarios which we believe to be either typical or limiting cases for the aldehyde source strength at this site. The four scenarios were: A) acetaldehyde production equal to loss $\left.\left(\mathrm{P}_{\text {acet }}=\mathrm{L}_{\mathrm{acet}}\right), \mathrm{B}\right)$ acetaldehyde production equal to zero $\left.\left(\mathrm{P}_{\text {acet }}=0\right), \mathrm{C}\right)$ acetaldehyde production equal to 1.5 times loss $\left(\mathrm{P}_{\mathrm{acet}}=1.5 \mathrm{~L}_{\mathrm{acet}}\right)$ and D) $\mathrm{P}_{\text {acet }}=1.5 \mathrm{~L}_{\text {acet }}$ from sunrise to noon, and $\mathrm{P}_{\text {acet }}=(2 / 3) \mathrm{L}_{\text {acet }}$ from noon to sunset. Acetaldehyde loss $\left(\mathrm{L}_{\text {acet }}\right)$ was determined by its reaction rate with the $\mathrm{OH}$ field defined above. The acetaldehyde concentrations produced in these scenarios are shown in Fig. 5. Scenario A is a close match to the observations on 12 September 2001. Scenario D produces acetaldehyde concentrations similar to that observed on 13 September 2001. Scenarios B and C represent limiting cases that describe behavior of acetaldehyde outside the range of the observations and thus put useful bounds on the comparison of the time dependent and steady state calculations. 


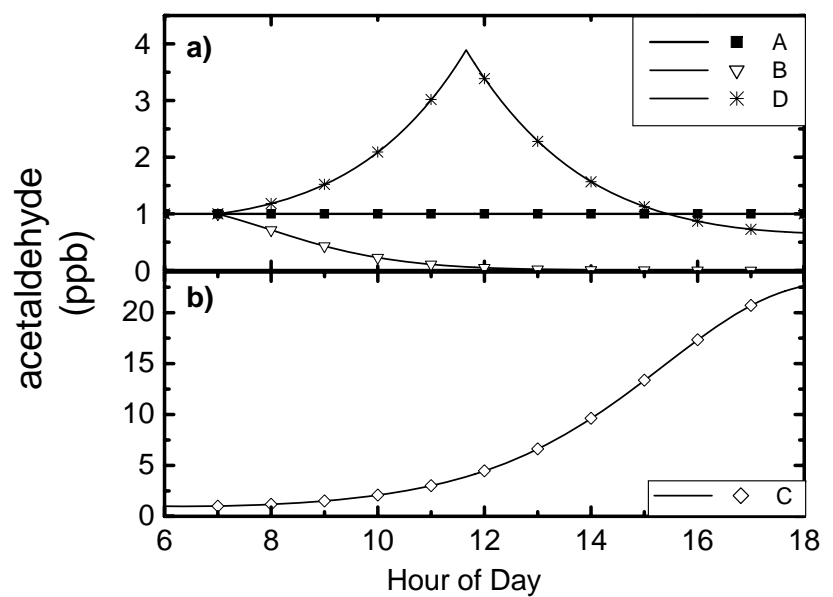

Fig. 5. Model inputs used to compare time dependent and steady state models. (a) $\mathrm{OH}$ (scaled to PAR), (b) $\mathrm{NO} / \mathrm{NO}_{2}$ ratio, and (c) average observed temperature versus time of day.

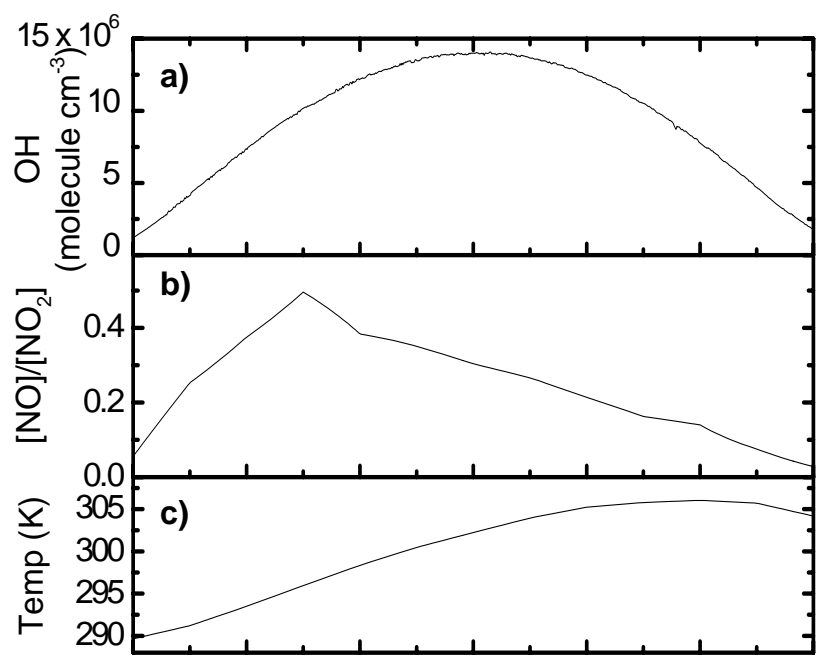

Fig. 6. Acetaldehyde inputs used to compare time dependent and steady state models: (a) The acetaldehyde concentrations for scenarios A (constant), $\mathrm{B}\left(\mathrm{P}_{a}=0\right), \mathrm{D}(\mathrm{P}>\mathrm{L}$ in morning, $\mathrm{P}<\mathrm{L}$ in evening) and (b) the acetaldehyde concentrations in scenario $\mathrm{C}$ $\left(\mathrm{P}>\mathrm{L}, \mathrm{P}=1.25^{*} \mathrm{~L}\right)$.

The calculations were initialized using $0.300 \mathrm{ppb}$ for [PAN] and $1.0 \mathrm{ppb}$ for [acetaldehyde]. These are typical values at sunrise. We used as input the median diurnal cycles of the ratio $[\mathrm{NO}] /\left[\mathrm{NO}_{2}\right]$, temperature, and an estimate for $\mathrm{OH}$ ranging from $1 \times 10^{6}$ to $1.4 \times 10^{7}$ molecule $\mathrm{cm}^{-3}$ at noon (the highest value based on the results of Dillon et al. (2002) who fit a Lagrangian model describing mixing and oxidation of a range of VOC measurements to estimate $\mathrm{OH}$ ). The temporal variation in $\mathrm{OH}$ was estimated by scaling to PAR. The parameters are shown in Fig. 6, with the highest modeled noontime $\mathrm{OH}$.

Figures $7 \mathrm{a}$ and $\mathrm{b}$, respectively, show the steady state and

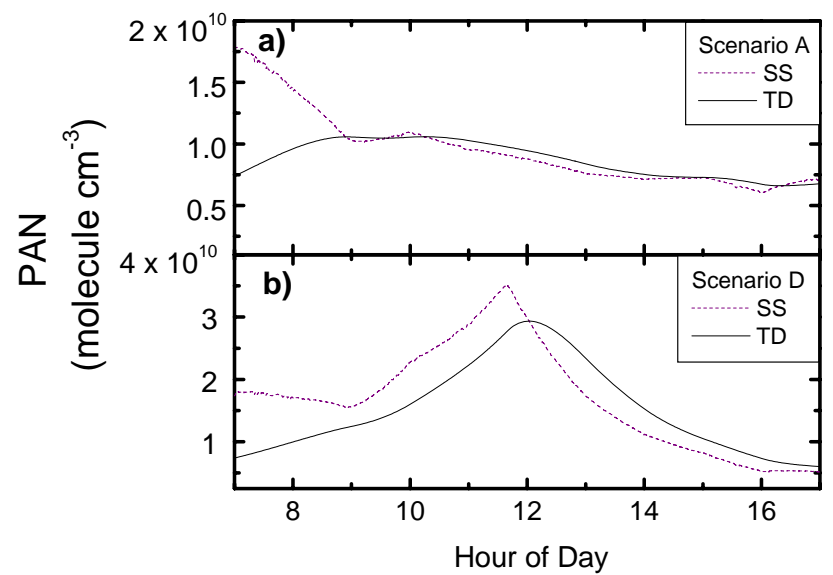

Fig. 7. PAN concentration results from the comparison of the steady state and time dependent models. (a) the diurnal profile of calculated PAN concentrations using scenario A with measured acetaldehyde concentrations as input $\left([\mathrm{PAN}]_{T D}=\right.$ solid line, $[\mathrm{PAN}]_{S S}=$ dotted line). (b) The diurnal profile of calculated PAN concentrations from scenario $\mathrm{D}(\mathrm{PAN}]_{T D}=$ solid line, $[\mathrm{PAN}]_{S S}=$ dotted line).

time dependent calculations of PAN for scenarios A and D. Figure 8 shows the ratio of the steady state (SS) to the time dependent (TD) calculations of PAN versus time of day for all 4 scenarios. After an initial spin up time of about two hours, the SS calculation is within $\pm 30 \%$ of the TD calculation through the remainder of the day for scenarios $\mathrm{A}, \mathrm{C}$ and D. For scenario A when acetaldehyde concentrations are constant, the steady state calculation agrees with the TD calculation to within $\pm 10 \%$. For scenario B, where the production of acetaldehyde is zero, the acetaldehyde concentration is changing most rapidly compared to the PAN lifetime. As a result, the time dependent calculation has higher PN concentrations than steady state. Even in this scenario the time dependent calculation differs from the steady state approximation by only $60 \%(\mathrm{SS} / \mathrm{TD}=0.4)$. For scenario $\mathrm{C}$, the net acetaldehyde lifetime is comparable to the PAN lifetime and the steady state calculation predicts $40 \%$ more PAN than the time dependent calculation before 11:00 h. The two calculations for scenario $\mathrm{C}$ converge to within $25 \%$ at noon. The sign of the SS/TD ratio reflects that production of acetaldehyde is larger than losses in scenario C. Scenario D represents a situation such as on 13 September where there is net production of acetaldehyde in the morning but a decrease during the afternoon. This scenario combines the effects seen in scenarios $\mathrm{B}$ and $\mathrm{C}$. The steady state calculation overestimates PAN in the morning, crosses through a point where the two calculations agree at about noon before underestimating PAN for the remainder of the afternoon. We tested whether the comparison of time-dependent and steady state calculations had a strong sensitivity to the assumed $\mathrm{OH}$. Using a more than tenfold decrease in $\mathrm{OH}, 1 \times 10^{6}$ at noon, the differences between 
Table 3. Measured and estimated aldehydes shown with their rate constant with $\mathrm{OH}$, noon lifetime $\left(\mathrm{OH}=1 \times 10^{7} \mathrm{molecule} \mathrm{cm}^{-3}\right)$, mean daily concentration for each steady state model (M1, M2 and M3) and branching ratio to peroxy nitrates.

\begin{tabular}{lllllll}
\hline aldehyde & $\begin{array}{l}\mathrm{k}_{\mathrm{OH}}^{\mathrm{a}} \\
\left(\mathrm{cm}^{3} \text { molecule }\right.\end{array}$ & & $\begin{array}{l}\left.\tau_{\mathrm{OH}}^{\mathrm{b}} \mathrm{s}^{-1}\right) \\
(\mathrm{h})\end{array}$ & \multicolumn{3}{c}{$\begin{array}{l}\text { ave. daytime } \\
(\mathrm{ppb})\end{array}$} \\
\hline acetaldehyde & $1.58 \times 10^{-11}$ & 1.2 & 1.2 & 1.2 & 1.2 & 1 \\
propanal & $1.96 \times 10^{-11}$ & 1 & $0.14^{*}$ & $70.14^{*}$ & $0.14^{*}$ & $0.95^{*}$ \\
butanal & $2.35 \times 10^{-11}$ & 0.8 & - & $0.047^{*}$ & $70.047^{*}$ & $0.90^{*}$ \\
isobutanal & $2.63 \times 10^{-11}$ & 0.8 & - & $0.047^{*}$ & $0.047^{*}$ & $90^{*}$ \\
pentanal & $2.99 \times 10^{-11}$ & 0.6 & 0.093 & 0.093 & 0.093 & $0.82^{*}$ \\
hexanal & $3.17 \times 10^{-11}$ & 0.6 & 0.14 & 0.14 & 0.14 & $0.74^{*}$ \\
heptanal & $3.03 \times 10^{-11 c}$ & 0.6 & - & $0.093^{*}$ & $0.093^{*}$ & $0.66^{*}$ \\
octanal & $3.17 \times 10^{-11 c}$ & 0.6 & - & $0.093^{*}$ & $0.093^{*}$ & $0.58^{*}$ \\
nonanal & $3.6 \times 10^{-11 d}$ & 0.5 & - & $0.093^{*}$ & $0.093^{*}$ & 0.5 \\
methacrolein & $3.35 \times 10^{-11}$ & 0.6 & 0.27 & 0.27 & 0.27 & 0.45 \\
unknown PA source & $1.58 \times 10^{-11}$ & 1.2 & - & - & $3.6^{*}$ & 1 \\
\hline
\end{tabular}

a Atkinson et al. (1994) unless otherwise stated

b $[\mathrm{OH}]=1 \times 10^{7}$ molecule $\mathrm{cm}^{-3}$.

c estimated from Kwok et al. (1995)

${ }^{\mathrm{d}}$ Hurst-Bowman et al. (2003)

* estimated

the steady state and time dependent calculations decreased slightly for scenarios B, C, and D at all times of the day. Steady-state and time dependent calculations using the lower $\mathrm{OH}$ agreed less well during the rush hour when the $\mathrm{NO} / \mathrm{NO}_{2}$ ratio is highest for scenario $\mathrm{A}$. The steady-state/time dependent model disagreement is the highest when the ratio of the rate of PA radical generation to the rate of decomposition of PNs is approximately 2 (typically this ratio is close to 10).

Most of the observations have similar diurnal patterns to scenarios A or D, and we interpret the comparisons presented in this section to indicate that the steady state approximation for PN to aldehyde ratios is accurate to $30 \%$ or better outside of the rush hour periods. We note that one implication of our conclusions that PNs are in steady-state with $\mathrm{NO}_{\mathrm{x}}$ is that they should not be thought of as terminal sinks for $\mathrm{NO}_{\mathrm{y}}$ but rather as part of the available $\mathrm{NO}_{\mathrm{x}}$.

4.1 Partitioning of $\Sigma$ PNs and estimates of $\mathrm{OH}$ : model approach

We calculate $\Sigma$ PNs as the sum of steady state expressions (EQN 3) for each individual peroxy nitrate:

$$
\begin{aligned}
\Sigma \mathrm{PNs}= & \frac{\beta * \mathrm{k}_{1 i}[\mathrm{OH}] *[\text { acet }]}{\mathrm{k}_{-2}(1-\beta)+\mathrm{k}_{4 i}[\mathrm{OH}]}+\frac{\beta * \alpha_{i} * \mathrm{k}_{1 i}[\mathrm{OH}] *[\mathrm{MACR}]}{\mathrm{k}_{-2}(1-\beta)+\mathrm{k}_{4 i}[\mathrm{OH}]}+ \\
& \frac{\beta * \alpha_{i} * \mathrm{k}_{1 i}[\mathrm{OH}] *[\mathrm{ptnl}]}{\mathrm{k}_{-2}(1-\beta)+\mathrm{k}_{4 i}[\mathrm{OH}]}+\frac{\beta * \alpha_{i *} \mathrm{k}_{1 i}[\mathrm{OH}] *[\mathrm{hxnl}]}{\mathrm{k}_{-2}(1-\beta)+\mathrm{k}_{4 i}[\mathrm{OH}]}+\ldots
\end{aligned}
$$

The reaction rate for each aldehyde with $\mathrm{OH}\left(\mathrm{k}_{1 i}\right)$, each $\mathrm{PN}_{i}$ with $\mathrm{OH}\left(\mathrm{k}_{4 i}\right)$ and the branching ratio of aldehydic abstraction $\left(\alpha_{i}\right)$ by $\mathrm{OH}$ are specific to each $\mathrm{PN}_{i} /$ aldehyde $_{i}$ pair. For example, MPAN has a significant loss to reaction with $\mathrm{OH}$, producing products that are not $\Sigma$ PNs (Orlando et al., 2002). The reactions of other PNs with $\mathrm{OH}$ are slow, but the magnitudes may increase with carbon number (Jenkin et al., 1997). The reactions of each peroxy-radical with $\mathrm{NO}_{2}$ and $\mathrm{NO}$ (rate constants $\mathrm{k}_{2}$ and $\mathrm{k}_{3}$ ) are estimated to be the same for all peroxyacyl radicals. The dissociation of each PN back to $\mathrm{NO}_{2}\left(\mathrm{k}_{-2}\right)$ is also estimated to be the same as that measured for PAN (Atkinson et al., 1997, 2004). The unique solution to Eq. (5) results in determination of the $\mathrm{OH}$ concentration and the concentrations for individual peroxy nitrates for each point in the data set. In our tests of the accuracy of the steady-state model we calculated PAN from aldehydes and an assumed profile of $\mathrm{OH}$, the accuracy estimate of $30 \%$ for that relationship also applies to calculations of $\mathrm{OH}$ using measured $\Sigma \mathrm{PNs}$ and aldehydes, if the assumption that the $\Sigma$ PNs and aldehydes are in steady-state holds and if the aldehyde sources of $\mathrm{PA}_{i}$ represented in the model are a complete set. We solve Eq. (5) for three models: M1) using the observed aldehydes and constraining the relationship of PPN to PAN, M2) adding to M1 an estimate of the concentration for a broader range of aldehydes and M3) adding to M2 an additional source of PAN. One of the more abundant and well-studied PNs is PPN. However, we do not have a measurement of propanal, the aldehyde precursor to PPN. At inland sites in California, the PPN/PAN ratio has been observed to be 0.15 with little variation (Grosjean, 2003, and references therein). Thus we fix the PPN to PAN ratio at 0.15 and adjust the propanal concentration accordingly in all three models. 
Table 4. Distribution of peroxy nitrates as calculated using aldehydes in Table 3 and Eq. (6). The percent of total peroxy nitrates, the ratio to PAN and the median mixing ratio are given for each model.

\begin{tabular}{llllllllllll}
\hline PN & \multicolumn{3}{c}{$\% \Sigma$ PNs } & \multicolumn{4}{c}{ PN:PAN ratio } & \multicolumn{3}{c}{ daytime average (ppb) } & $\mathrm{k}_{\mathrm{OH}}$ \\
& $\mathrm{M} 1$ & $\mathrm{M} 2$ & $\mathrm{M} 3$ & $\mathrm{M} 1$ & $\mathrm{M} 2$ & $\mathrm{M} 3$ & $\mathrm{M} 1$ & $\mathrm{M} 2$ & $\mathrm{M} 3$ & $\times 10^{-12}\left(\mathrm{~cm}^{3} \mathrm{molecule}^{-1} \mathrm{~s}^{-1}\right)$ \\
\hline PAN & $65.2 \%$ & $50 \%$ & $69.7 \%$ & 1 & 1 & 1 & 0.58 & 0.45 & 0.62 & $0.03^{\mathrm{a}}$ \\
$\mathrm{PPN}$ & $9.8 \%$ & $7.5 \%$ & $10.4 \%$ & 0.15 & 0.15 & 0.15 & 0.087 & 0.067 & $0.092 \mathrm{~N} . A$. & \\
PnBN & - & $2.5 \%$ & $1.1 \%$ & - & 0.05 & 0.02 & - & 0.022 & 0.010 & $4.7^{*}$ \\
PiBN & - & $2.5 \%$ & $1.1 \%$ & - & 0.05 & 0.02 & - & 0.022 & 0.010 & $4.7^{*}$ \\
$\mathrm{c}_{5}$ PAN & $7.7 \%$ & $5.8 \%$ & $2.6 \%$ & 0.12 & 0.12 & 0.04 & 0.069 & 0.054 & 0.023 & $6.9^{*}$ \\
$\mathrm{C}_{6}$ PAN & $11 \%$ & $8.5 \%$ & $3.9 \%$ & 0.17 & 0.17 & 0.06 & 0.099 & 0.076 & 0.034 & $5^{*}$ \\
$\mathrm{C}_{7}$ PAN & - & $4.7 \%$ & $2.1 \%$ & - & 0.10 & 0.03 & - & 0.045 & 0.018 & $8.5^{\dagger}$ \\
$\mathrm{C}_{8}$ PAN & - & $4.4 \%$ & $2.0 \%$ & - & 0.09 & 0.03 & - & 0.040 & 0.018 & $8.5^{\dagger}$ \\
$\mathrm{C}_{9}$ PAN & - & $8.5 \%$ & $3.9 \%$ & - & 0.17 & 0.06 & - & 0.076 & 0.034 & $8.5^{\dagger}$ \\
MPAN & $6.3 \%$ & $5.5 \%$ & $3.2 \%$ & 0.10 & 0.11 & 0.04 & 0.057 & 0.049 & 0.028 & $25.0^{\mathrm{b}}$ \\
\hline
\end{tabular}

* Rate coefficients of PNs with $\mathrm{OH}$ are based on those reported in the Master Chemical Mechanism where laboratory data are not available.

$\dagger$ estimated

a (Talukdar et al., 1995)

b (Orlando et al., 2002)

M1 consists of all observed aldehydes and a fixed ratio of PPN:PAN of 0.15.

M2 includes all aldehydes from M1 with additional aldehydes with relative abundances estimated to be similar to those observed at other sites (outlined in Table 3).

M3 included aldehydes from M2 with an additional source of PA radicals.

In M2 we estimate the mixing ratio of other aldehydes based on prior observations at other urban locations (Grossman et al., 2003; McClenny et al., 1998; Wedel et al., 1998; Hurst-Bowman et al., 2003). We include isobutanal, along with $\mathrm{C}_{4}, \mathrm{C}_{7}, \mathrm{C}_{8}$, and $\mathrm{C}_{9}$ n-aldehydes. $\mathrm{C}_{4}, \mathrm{C}_{7}$ and $\mathrm{C}_{8}$ aldehydes are estimated to occur at the same mixing ratio as pentanal and nonanal is estimated to be twice as abundant as pentanal. Table 3 lists the rate constants (298K) for the reaction of $\mathrm{C}_{2}-\mathrm{C}_{9}$ aldehydes with $\mathrm{OH}$ along with the average noontime concentrations that we observed or that we estimate. The branching ratio between aldehyde- $\mathrm{H}$ abstraction, which leads to PN formation, and alkyl-H abstraction, which we assume does not, increases with the carbon chain length of the $\mathrm{n}$-aldehydes. For propanal, the ratio of $\mathrm{OH}$ abstraction at the aldehydic hydrogen to the alkyl hydrocarbons is estimated to be $95 \%$ and for butanal 90\% (Jenkin et al., 1997) The ratio of aldehyde-H abstraction to alkyl abstraction for nonanal was calculated to be $50 \%$ by Hurst-Bowman et al. (2003). As an estimate for other species we smoothly connect the butanal and nonanal points, decreasing the reaction at the aldehydic hydrogen by $8 \%$ per carbon ( $82 \%$ for pentanal, $74 \%$ for hexanal, $66 \%$ for heptanal and $58 \%$ for octanal). For methacrolein, observations indicate $45 \%$ of $\mathrm{OH}$ reactions abstract the aldehydic hydrogen (Orlando et al., 1999).

In M3, we include an added source of PA radicals contributing to the formation of PAN. Roberts et al. (2001) suggest there is a large source of PA radicals other than acetaldehyde based on their observations in Nashville, TN, an urban area where isoprene dominates local photochemistry. One suggestion for this source is methylglyoxal (Romero et al., 2005), which is a product of isoprene oxidation and thus likely abundant both in Granite Bay, CA and in Nashville, TN. Based on the calculations by Roberts et al. (2001) the missing source of PA could be 2 to 3 times larger than the PA source from acetaldehyde. For M3, we add an additional source of PA radicals that fixes PAN at $70 \%$ of $\Sigma$ PNs.

\subsection{Partitioning of $\Sigma$ PNs and estimates of OH: model re- sults}

The calculated partitioning of peroxy-nitrates using the inputs described above is shown in Table 4. PAN is calculated to be the largest portion of $\Sigma$ PNs, $65 \%$ for M1, $50 \%$ in M2, and constrained to be $70 \%$ for M3. For M1, PPN, $\mathrm{C}_{5}$ PAN, $\mathrm{C}_{6} \mathrm{PAN}$ and MPAN are 9.8, 7.7, 11 and $6.3 \%$ of $\Sigma$ PNs, respectively. In M2, PNs that have never been observed in the atmosphere are estimated to contribute about $1 / 3$ of the total peroxy nitrates, with $\mathrm{C}_{9} \mathrm{PAN}$ and $\mathrm{C}_{6} \mathrm{PAN}$ the most abundant of these, each at $8.5 \%$ of $\Sigma$ PNs. Comparisons of $\Sigma$ PNs with measurements of individual PNs suggest that the $1 / 3$ contribution for previously unmeasured PNs is too large (Roberts et al., 2003; Rosen, 2004; Wooldridge et al., 2007 ${ }^{1}$ ). The contribution of PAN to $\Sigma$ PNs observed during our previous measurements was never less than $70 \%$ and was typically

\footnotetext{
${ }^{1}$ Wooldridge, P. J., Perring, A., and Cohen, R. C.: Total Peroxy Nitrates: the Thermal Dissociation-Laser Induced Fluorescence Technique and Comparisons to Speciated PAN Measurements, in preparation, 2007.
} 


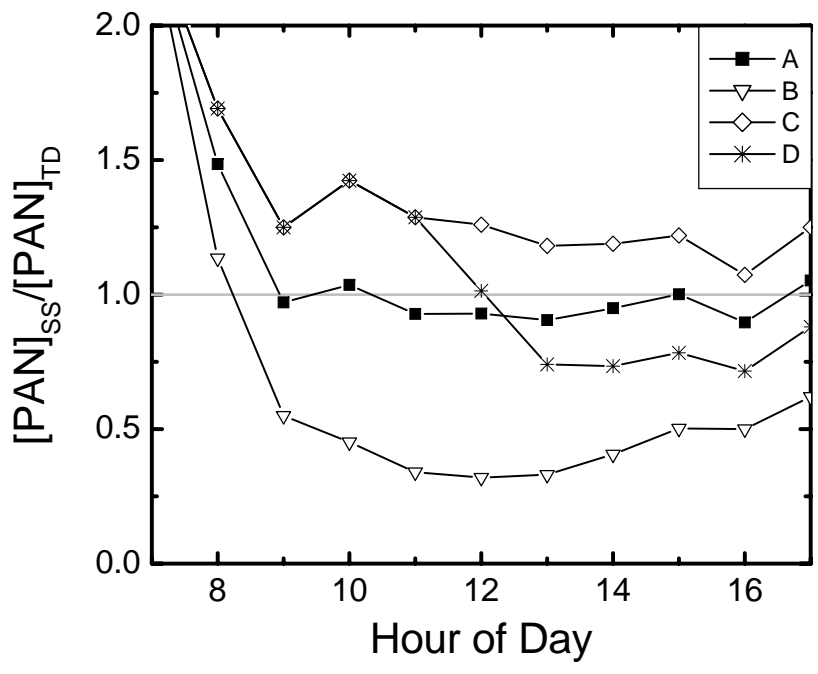

Fig. 8. Ratio of calculated PAN concentrations for the steady state and time dependent models $\left([\mathrm{PAN}]_{S S} /[\mathrm{PAN}]_{T D}\right)$ versus time of day for all the 4 scenarios: Scenario A (-), Scenario B (- $\nabla-)$, Scenario $C(-\diamond-)$, and Scenario D $\left(-*^{-}\right)$. (Scenarios $C$ and $D$ are coincident before noon.)

$80 \%$. Thus M3 represents a situation that is consistent with the lower end of the prior observations of the PAN/ $\Sigma$ PNs ratio. We found it necessary to insert a source of PA radicals that is 3 times the acetaldehyde source alone in order to increase the PAN fraction of the $\Sigma$ PNs. In our calculation we have implemented this increase by simply increasing the concentration of acetaldehyde. This has the effect of reducing the calculated $\mathrm{OH}$ substantially because of the inverse relationship between the $\mathrm{OH}$ that is calculated by rearranging Eqs. (3) and (5) and aldehyde sources of PNs. If the sole source were instead photolysis of methylglyoxal, with a noon photolysis rate coefficient of $2 \times 10^{-4} \mathrm{~s}^{-1}, 0.75 \mathrm{ppb}$ of methylglyoxal would be required. This would result in a much higher calculated concentration of $\mathrm{OH}$. However this concentration of methylglyoxal is unrealistically large as the average observed daytime concentrations of methacrolein and methyl vinyl ketone which are considered to be precursors to methylglyoxal are only 0.6 and $0.3 \mathrm{ppb}$, respectively. We conclude that an additional source of PA radicals other than acetaldehyde must be present in the atmosphere near Sacramento urban and likely in regions affected by biogenic emissions more generally.

The calculated partitioning of $\Sigma$ PNs varies little over the course of the day because the ratio of aldehydes varies little, although some of the PNs may have much lower mixing ratios in the background atmosphere than PAN and may therefore be more affected by mixing, especially early in the day. The peak abundance of each peroxy nitrate and its ratio to PAN from M3 are very similar to other measurements. For example, Roberts et al. $(1998,2001,2002)$ report daytime MPAN to PAN ratios ranging from 3-9\% during experiments

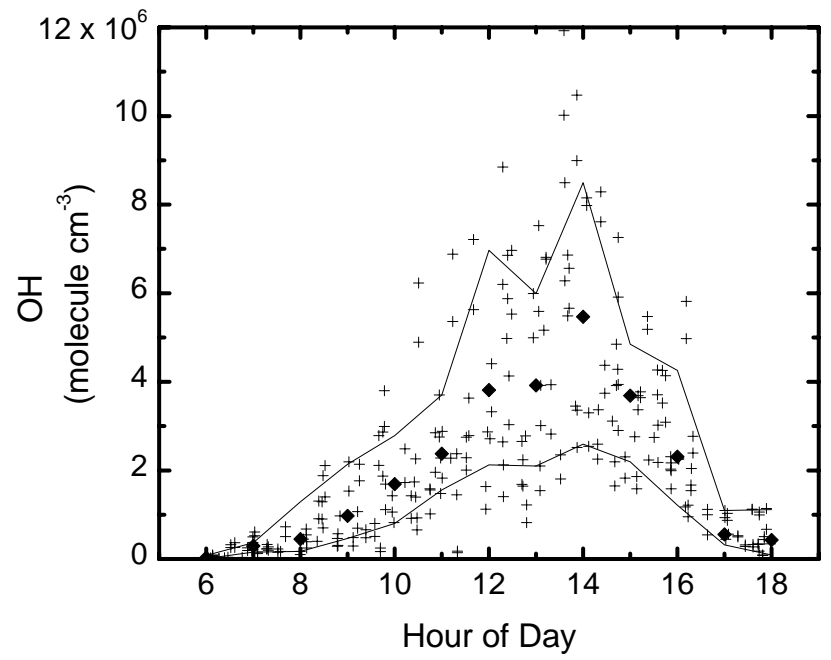

Fig. 9. Diurnal profile of calculated $\mathrm{OH}$ concentrations from M3. Median points per 1-h bin are plotted in black diamonds, $\pm 1 \sigma$ from the mean hourly points are plotted in solid line.

in Nashville (1994, 1995, 1999) and in Houston (2000), with average concentrations for MPAN of $0.048 \mathrm{ppb}$ (Nashville, 1994), $0.037 \mathrm{ppb}$ (Nashville, 1995), $0.084 \mathrm{ppb}$ (Nashville, 1999) and $0.030 \mathrm{ppb}$ (Houston, 2000). Our estimates of the same quantities are $6 \%$ and $0.030 \mathrm{ppb}$ using M3. M1 and M2 both result in MPAN to PAN ratios of 10-11\%, higher than any of these prior measurements. Roberts et al. (2001) report average daytime PiBN/PAN ratios of $\sim 2 \%$ at La Porte, TX. Our estimate of the PiBN/PAN ratio from M3 is $2 \%$ and for M2 it is 5\%. The distribution of PNs in M3 has a contribution of $15 \%$ from PNs that have never previously been measured in ambient samples. We believe this is too high. The most likely reason is that $\Sigma$ PNs are slightly out of steady state, although the possibilities that the higher PNs have much faster atmospheric removal processes or that PAN sources other than acetaldehyde are even larger than we speculated in M3 should also be explored.

The calculated $\mathrm{OH}$ (M3) has a strong diurnal cycle with peaks $1-3 \mathrm{~h}$ after local noon ranging from 2 $7 \times 10^{6}$ molecule $\mathrm{cm}^{-3}$ on different days (Figs. $4 \mathrm{~b}$ and 9 ). The median results are $4.0 \times 10^{6}$ and $5.8 \times 10^{6}$ molecule $\mathrm{cm}^{-3}$ at 12:00 $\mathrm{h}$ and $14: 00 \mathrm{~h}$, respectively. The inverse relation between modeled PN sources (Eqs. 3 and 5) results in $\mathrm{OH}$ calculated using M1 that is $250 \%$ larger and M2 that $100 \%$ larger than that calculated with M3. If some large fraction of the PAN production is photolysis of an aldehyde instead of oxidation by $\mathrm{OH}$, then the $\mathrm{OH}$ could be as high as that indicated by M2. Figure $4 \mathrm{~b}$ shows the calculated $\mathrm{OH}$ (M3) on 11 September-16 September. Notice that for very different $\Sigma \mathrm{PN}$ and acetaldehyde concentrations, similar $\mathrm{OH}$ profiles are derived. For example, on both 11 September and 13 September, the modeled $\mathrm{OH}$ peaks at $2 \times 10^{6}$ molecule $\mathrm{cm}^{-3}$ while acetaldehyde and $\Sigma$ PN measurements peak at midday 
on 13 September at concentrations roughly twice that of noontime concentrations on 11 September. Given the approximations that are used to calculate $\mathrm{OH}$, these specific values should be interpreted with caution until a more extensive comparison of this method for inferring $\mathrm{OH}$ and direct $\mathrm{OH}$ measurements can be made. For example, it is also possible that we underestimate the $\mathrm{OH}$ because of treating the additional PAN source as acetaldehyde rather than assuming it is photolytic.

The diurnal profile of the calculated $\mathrm{OH}$ during the entire campaign is shown in Fig. 9. The black diamonds represent the mean values and the solid lines $\pm 1 \sigma$ for each 1 -h bin $\mathrm{u}$ The $\mathrm{OH}$ we calculate is lower than the values derived from oxidation/dilution analyses of observations downwind of Granite Bay within the Sacramento plume by Dillon et al. (2002), Schade et al. (2002) and Dreyfus et al. (2002). Lower $\mathrm{OH}$ at Granite Bay than in the average over the Sacramento plume is expected because the Granite Bay site is $\mathrm{NO}_{\mathrm{x}}$ saturated and $\mathrm{OH}$ should increase as $\mathrm{NO}_{\mathrm{x}}$ decreases downwind (Murphy et al., 2006a, b). The asymmetry in the calculated $\mathrm{OH}$ abundances about noon is consistent with recent measurements of $\mathrm{OH}$ by Martinez et al. (2002) and Ren et al. (2003) who report maxima at $\sim 02: 00$ p.m. Similar noontime $\mathrm{OH}$ concentrations have been reported for Los Angeles at 3-6 $\times 10^{6}$ molecule $\mathrm{cm}^{-3}$ (George et al., 1999), Birmingham, UK in the wintertime (mean of $3 \times 10^{6}$ molecule $\mathrm{cm}^{-3}$ ) (Heard et al., 2004), Wittle, UK outside of London at $2 \times 10^{6}$ molecule $\mathrm{cm}^{-3}$ (Emmerson et al., 2007) and Munich, Germany at $4.5-7.4 \times 10^{6}$ molecule $\mathrm{cm}^{-3}$ (Handisides et al., 2003).

\section{Conclusions}

We describe observations of $\Sigma$ PNs, aldehydes, $\mathrm{NO}_{2}$ and $\mathrm{O}_{3}$ at Granite Bay, CA from 19 July-16 September 2001. The observations are used to characterize the partitioning of $\Sigma$ PNs and to demonstrate the possibility of deterring the mixing ratio of $\mathrm{OH}$ if the sources of PNs were accurately known. We calculate that PAN is likely $65 \%$ of $\Sigma$ PNs if acetaldehyde is the only PAN source, a value too low to be consistent with prior measurements, suggesting a prominent role for another source of PA radicals. Constraining PAN to be $70 \%$ of $\Sigma$ PNs and PPN to be $15 \%$ of PAN, we estimate MPAN is $3 \%$ of $\Sigma$ PNs, PiBn is $1 \%$ and that the sum of $\mathrm{C}_{5}$ and larger PNs that have not previously been observed outside the laboratory to be $15 \%$ of $\Sigma$ PNs. This value for the fraction of $\Sigma$ PNs that are species that have never before been observed in the atmosphere is likely too high. We suspect that this is due to PNs being out of steady state with their sources. We also calculate a diurnal profile of $\mathrm{OH}$ at the site that is in reasonable correspondence with direct observations at other locations and derive a median $\mathrm{OH}$ of $2.6 \times 10^{6}$ molecule $\mathrm{cm}^{-3}$ at noon.
We have compared a steady state and time dependent calculation for PNs showing that the steady state calculation is accurate to $30 \%$. This implies a relatively rapid interconversion between $\mathrm{NO}_{\mathrm{x}}$ and $\Sigma$ PNs in urban plumes, such that $\Sigma$ PNs do not represent a terminal sink of $\mathrm{NO}_{\mathrm{x}}$. The quantities $\mathrm{NO}_{\mathrm{x}}, \mathrm{NO}_{\mathrm{y}}$ and $\mathrm{NO}_{\mathrm{z}}$ have been widely interpreted based on the assumption that $\mathrm{NO}_{z}$ is quite slowly (if at all) returned to the $\mathrm{NO}_{\mathrm{x}}$ pool. Our results suggest that rethinking the use of these quantities is necessary. We calculate that peroxy nitrates are usually in steady state with $\mathrm{NO}_{2}$ on a time scale of 40 minutes. In the urban plume described in this manuscript, $\Sigma$ PNs range from $1 / 4$ to about $1 / 2$ of $\mathrm{NO}_{2}$ during midday. This short lifetime and the high relative concentrations of peroxy nitrates compared to $\mathrm{NO}_{\mathrm{x}}$ imply that the PNs component of $\mathrm{NO}_{z}$ can buffer $\mathrm{NO}_{\mathrm{x}}$ concentrations in the planetary boundary layer. Thus as the Sacramento plume (and by analogy many other urban plumes) is transported downwind PNs decompose keeping $\mathrm{NO}_{\mathrm{x}}$ higher than would be the case if PNs were a permanent $\mathrm{NO}_{\mathrm{x}}$ sink. As an alternative to the usual definitions of $\mathrm{NO}_{\mathrm{x}}$ and $\mathrm{NO}_{\mathrm{z}}$ we suggest that $\mathrm{NO}_{\mathrm{x}}+\mathrm{PNs}$ and $\mathrm{HNO}_{3}+\mathrm{ANs}$ (or $\mathrm{NO}_{\mathrm{y}}-\mathrm{NO}_{\mathrm{x}}-\mathrm{PNs}$ ) be used in analyses of the correlations of $\mathrm{O}_{3}$ and $\mathrm{NO}_{\mathrm{x}}$ in warm urban plumes.

Acknowledgements. We gratefully acknowledge the U.S. Department of Energy support for measurements under contract AC03-76SF0009 and National Science Foundation support for analysis under grant ATM-0138669. D. Millet also acknowledges DOE GCEP fellowship for funding. We are grateful to the Eureka Union School District for the use of the measurement site.

Edited by: U. Pöschl

\section{References}

Atkinson, R. and Lloyd, A. C.: Evaluation of Kinetic and Mechanistic Data For Modeling of Photochemical Smog, J. Phys. Chem. Ref. Data, 13, 315-444, 1984.

Atkinson, R.: Gas-Phase Tropospheric Chemistry of OrganicCompounds, J. Phys. Chem. Ref. Data, 2, 1-216, 1994.

Atkinson, R., Baulch, D. L., Cox, R. A., Hampson, R. F., Kerr, J. A., Rossi, M. J., and Troe, J.: Evaluated kinetic and photochemical data for atmospheric chemistry: Supplement VI - IUPAC subcommittee on gas kinetic data evaluation for atmospheric chemistry, J. Phys. Chem. Ref. Data, 26, 1329-1499, 1997.

Atkinson, R., Baulch, D. L., Cox, R. A., Crowley, J. N., Hampson, R. F., Hynes, R. G., Jenkin, M. E., Rossi, M. J., and Troe, J.: Evaluated kinetic and photochemical data for atmospheric chemistry: Volume $\mathrm{I}$ - gas phase reactions of $\mathrm{O}_{\mathrm{x}}, \mathrm{HO}_{\mathrm{x}}, \mathrm{NO}_{\mathrm{x}}$ and $\mathrm{SO}_{\mathrm{x}}$ species, Atmos. Chem. Phys., 4, 1461-1738, 2004, http://www.atmos-chem-phys.net/4/1461/2004/.

Beine, H. J., Jaffe, D. A., Blake, D. R., Atlas, E., and Harris, J.: Measurements of PAN, alkyl nitrates, ozone, and hydrocarbons during spring in interior Alaska, J. Geophys. Res.-Atmos., 101, 12 613-12 619, 1996.

Blitz, M. A., Heard, D. E., Pilling, M. J., Arnold, S. R., and Chipperfield, M. P.: Pressure and temperature-dependent 
quantum yields for the photodissociation of acetone between 279 and $327.5 \mathrm{~nm}$, Geophys. Res. Lett., 31, L06111, doi:10.1029/2003GL018793, 2004.

Cleary, P. A., Wooldridge, P. J., and Cohen, R. C.: Laser-induced fluorescence detection of atmospheric $\mathrm{NO}_{2}$ with a commercial diode laser and a supersonic expansion, Appl. Opt., 41, 69506956, 2002.

Cleary, P. A., Murphy, J. G., Wooldridge, P. J., Day, D. A., Millet, D. B., McKay, M., Goldstein, A. H., and Cohen, R. C.: Observations of total alkyl nitrates within the Sacramento Urban Plume, Atmos. Chem. Phys. Discuss., 5, 4801-4843, 2005, http://www.atmos-chem-phys-discuss.net/5/4801/2005/.

Corsmeier, U., Kalthoff, N., Vogel, B., Hammer, M. U., Fiedler, F., Kottmeier, C., Volz-Thomas, A., Konrad, S., 5 Glaser, K., Neininger, B., Lehning, M., Jaeschke, W., Memmesheimer, M., Rappengluck, B., and Jakobi, G.: Ozone and PAN formation inside and outside of the Berlin plume - Process analysis and numerical process simulation, J. Atmos. Chem., 42, 289-321, 2002a.

Corsmeier, U., Kalthoff, N., Vogel, B., Hammer, M. U., Fiedler, F., Kottmeier, C., Volz-Thomas, A., Konrad, S., Glaser, K., Neininger, B., Lehning, M., Jaeschke, W., Memmesheimer, M., Rappenglueck, B., and Jakobi, G.: Ozone and PAN Formation Inside and Outside of the Berlin Plume - Process Analysis and Numerical Process Simulation, J. Atmos. Chem., 42, 289-321, $2002 b$

Day, D. A., Wooldridge, P. J., Dillon, M. B., Thornton, J. A., and Cohen, R. C.: A thermal dissociation laser-induced fluorescence instrument for in situ detection of $\mathrm{NO}_{2}$, peroxy nitrates, alkyl nitrates, and HNO3, J. Geophys. Res.-Atmos., 107, 4046, doi:10.1029/2001JD000779, 2002.

Day, D. A., Dillon, M. B., Wooldridge, P. J., Thornton, J. A., Rosen, R. S., Wood, E. C., and Cohen, R. C.: On alkyl nitrates, $\mathrm{O}_{3}$, and the "missing $\mathrm{NO}_{\mathrm{y}}$ ", J. Geophys. Res.-Atmos., 108, 4501, doi:10.1029/2003JD003685, 2003.

Dillon, M. B., Lamanna, M. S., Schade, G. W., Goldstein, A. H., and Cohen, R. C.: Chemical evolution of the Sacramento urban plume: Transport and oxidation, J. Geophys. Res.-Atmos., 107, 4045, doi:10.1029/2001JD000969, 2002.

Dreyfus, G. B., Schade, G. W., and Goldstein, A. H.: Observational constraints on the contribution of isoprene oxidation to ozone production on the western slope of the Sierra Nevada, California, J. Geophys. Res., 107, 4365, doi:10.1029/2001JD001490, 2002.

Emmerson, K. M., Carslaw, N., Carslaw, D. C., Lee, J. D., McFiggans, G., Bloss, W. J., Gravestock, T., Heard, D. E., Hopkins, J., Ingham, T., Pilling, M. J., Smith, S. C., Jacob, M. and Monks, P. S.: Free radical modelling studies during the UK TORCH Campaign in Summer 2003, Atmos. Chem. Phys., 7, 167-181, 2007, http://www.atmos-chem-phys.net/7/167/2007/.

Gaffney, J. S., Marley, N. A., Cunningham, M. M., and Doskey, P. V.: Measurements of peroxyacylnitrates (PANS) in Mexico City: implications for megacity air quality impacts on regional scales, Atmos. Environ., 33, 5003-5012, 1999.

Gaffney, J. S., Marley, N. A., Drayton, P. J., Doskey, P. V., Kotamarthi, V. R., Cunningham, M. M., Baird, J. C., Dintaman, J., and Hart, H. L.: Field observations of regional and urban impacts on $\mathrm{NO}_{2}$, ozone, UVB, and nitrate radical production rates in the Phoenix air basin, Atmos. Environ., 36, 825-833, 2002.

George, L. A., Hard, T. M., and O'Brien, R. J.: Measurement of free radicals $\mathrm{OH}$ and $\mathrm{HO}_{2}$ in Los Angeles smog, J. Geophys. Res.-Atmos., 104, 11 643-11 655, 1999.

Glavas, S. and Moschonas, N.: Determination of PAN, PPN, PnBN and selected pentyl nitrates in Athens, Greece, Atmos. Environ., 35, 5467-5475, 2001.

Grosjean, D.: Ambient PAN and PPN in southern California from 1960 to the SCOS97-NARSTO, Atmos. Environ., 37, S221S238, 2003.

Grossmann, D., Moortgat, G. K., Kibler, M., Schlomski, S., Bachmann, K., Alicke, B., Geyer, A., Platt, U., Hammer, M. U., Vogel, B., Mihelcic, D., Hofzumahaus, A., Holland, F., and Volz-Thomas, A.: Hydrogen peroxide, organic peroxides, carbonyl compounds, and organic acids measured at Pabstthum during BERLIOZ, J. Geophys. Res.-Atmos., 108, 8250, doi:10.1029/2001JD001096, 2003.

Handisides, G. M., Plass-Duelmer, C., Gilge, S., Bingemer, H., and Berresheim, H.: Hohenpeissenberg Photochemical Experiment (HOPE 2000): measurements and photostationary state calculations of $\mathrm{OH}$ and peroxy radicals, Atmos. Chem. Phys., 3, 15651588, 2003, http://www.atmos-chem-phys.net/3/1565/2003/.

Heard, D. E., Carpenter, L. J., Creasey, D. J., Hopkins, J. R., Lee, J. D., Lewis, A. C., Pilling, M. J., Seakins, P. W., Carslaw, N. and Emmerson, K. M.: High levels of the hydroxyl radical in the winter urban troposphere, Geophys. Res. Lett., 31, L18112, doi:10.1029/2004GL020544, 2004.

Hung, H. M., Katrib, Y., and Martin, S. T.: Products and mechanisms of the reaction of oleic acid with ozone and nitrate radical, J. Phys. Chem. A, 109, 4517-4530, 2005.

Hurst-Bowman, J., Basket, D. J., and Shepson, P. B.: Atmospheric chemistry of nonanal, Environ. Sci. Technol., 38, 2218-2225, 2003.

Jenkin, M. E., Saunders, S. M., and Pilling, M. J.: The tropospheric degradation of volatile organic compounds: A protocol for mechanism development, Atmos. Environ., 31, 81-104, 1997.

Kwok, E. S. C. and Atkinson, R.: Estimation of Hydroxyl Radical Reaction-Rate Constants For Gas- Phase Organic-Compounds Using a Structure-Reactivity Relationship - an Update, Atmos. Environ., 29, 1685-1695, 1995.

Martinez, M., Harder, H., Brune, W., Di Carlo, P., Williams, E., Hereid, D., Jobson, T., Kuster, W., Roberts, J., Trainer, M., Fehsenfeld, F. C., Hall, S., Shetter, R., Apel, E., Reimer, D., and Geyer, A.: The behavior of the hydroxyl and hydroperoxyl radicals during TexAQS2000, paper presented at AGU Fall Meeting, EOS Transactions, San Francisco, CA, USA, 2002.

McClenny, W. A., Daughtrey, E. H., Adams, J. R., Oliver, K. D., and Kronmiller, K. G.: Volatile organic compound concentration patterns at the New Hendersonville monitoring site in the 1995 Southern Oxidants Study in the Nashville, Tennessee, area, J. Geophys. Res.-Atmos., 103, 22 509-22 518, 1998.

McPeters, R. D.: TOMS, edited by NASA, 2001.

Millet, D. B., Donahue, N. M., Pandis, S. N., Polidori, A., Stanier, C. O., Turpin, B. J., and Goldstein, A. H.: Atmospheric volatile organic compound measurements during the Pittsburgh Air Quality Study: Results, interpretation, and quantification of primary and secondary contributions, J. Geophys. Res.-Atmos., 110, D07S07, doi:10.1029/2004JD004601, 2005.

Murphy, J. G., Day, D. A., Cleary, P. A., Wooldridge, P. J., Millet, D. B., Goldstein, A. H., and Cohen, R. C.: The weekend effect 
within and downwind of Sacramento: Part 1. Observations of ozone, nitrogen oxides, and VOC reactivity, Atmos. Chem. Phys. Discuss., 6, 11 427-11 464, 2006a.

Murphy, J. G., Day, D. A., Cleary, P. A., Wooldridge, P. J., Millet, D. B., Goldstein, A. H., and Cohen, R. C.: The weekend effect within and downwind of Sacramento: Part 2. Observational evidence for chemical and dynamical contributions, Atmos. Chem. Phys. Discuss., 6, 11 971-12 019, 2006b.

Noziere, B. and Barnes, I.: Evidence for formation of a PAN analogue of pinonic structure and investigation of its thermal stability, J. Geophys. Res.-Atmos., 103, 25 587-25 597, 1998.

Orlando, J. J., Tyndall, G. S., and Paulson, S. E.: Mechanism of the $\mathrm{OH}$-initiated oxidation of methacrolein, Geophys. Res. Lett., 26, 2191-2194, 1999.

Orlando, J. J., Tyndall, G. S., Bertman, S. B., Chen, W. C., and Burkholder, J. B.: Rate coefficient for the reaction of $\mathrm{OH}$ with $\mathrm{CH}_{2}=\mathrm{C}\left(\mathrm{CH}_{3}\right) \mathrm{C}(\mathrm{O}) \mathrm{OONO}_{2}$ (MPAN), Atmos. Environ., 36, 1895-1900, 2002.

Penkett, S. A. and Brice, K. A.: The spring maximum in photooxidants in the Northern Hemisphere troposphere, Nature (London, United Kingdom), 319, 655-657, 1986.

Rappengluck, B., Oyola, P., Olaeta, I., and Fabian, P.: The evolution of photochemical smog in the Metropolitan Area of Santiago de Chile, J. Appl. Meteorol., 39, 275-290, 2000.

Rappengluck, B., Melas, D., and Fabian, P.: Evidence of the impact of urban plumes on remote sites in the Eastern Mediterranean, Atmos. Environ., 37, 1853-1864, 2003.

Ren, X. R., Harder, H., Martinez, M., Lesher, R. L., Oliger, A., Shirley, T., Adams, J., Simpas, J. B., and Brune, W. H.: $\mathrm{HO}_{x}$ concentrations and $\mathrm{OH}$ reactivity observations in New York City during PMTACS-NY2001, Atmos. Environ., 37, 3627-3637, 2003

Roberts, J. M., Williams, J., Baumann, K., Buhr, M. P., Goldan, P. D., Holloway, J., Hubler, G., Kuster, W. C., McKeen, S. A., Ryerson, T. B., Trainer, M., Williams, E. J., Fehsenfeld, F. C., Bertman, S. B., Nouaime, G., Seaver, C., Grodzinsky, G., Rodgers, M., and Young, V. L.: Measurements of PAN, PPN, and MPAN made during the 1994 and 1995 Nashville Intensives of the Southern Oxidant Study: Implications for regional ozone production from biogenic hydrocarbons, J. Geophys. Res.-Atmos., 103, 22 473-22 490, 1998.

Roberts, J. M., Stroud, C. A., Jobson, B. T., Trainer, M., Hereid, D., Williams, E., Fehsenfeld, F., Brune, W., Martinez, M., and Harder, H.: Application of a sequential reaction model to PANs and aldehyde measurements in two urban areas, Geophys. Res. Lett., 28, 4583-4586, 2001.

Roberts, J. M., Flocke, F., Stroud, C. A., Hereid, D., Williams, E., Fehsenfeld, F., Brune, W., Martinez, M., and Harder, H.: Ground-based measurements of peroxycarboxylic nitric anhydrides (PANs) during the 1999 Southern Oxidants Study Nashville Intensive, J. Geophys. Res.-Atmos., 107, 4554, doi:10.1029/2001JD000947, 2002.

Roberts, J. M., Jobson, B. T., Kuster, W., Goldan, P., Murphy, P., Williams, E., Frost, G., Riemer, D., Apel, E., Stroud, C., Wiedenmyer, C., and Fehsenfeld, F.: An examination of the chemistry of peroxycarboxylic nitric anhydrides and related volatile organic compounds during Texas Air Quality Study 2000 using ground-based measurements, J. Geophys. Res., 108, 4495, doi:10.1029/2003JD003383, 2003.
Romero, M. T. B., Blitz, M. A., Heard, D. E., Pilling, M. J., Price, B., Seakins, P. W., and Wang, L. M.: Photolysis of methylethyl, diethyl and methylvinyl ketones and their role in the atmospheric $\mathrm{HO}_{\mathrm{x}}$ budget, Faraday Discuss., 130, 73-88, 2005.

Rosen, R. S.: Observations of $\mathrm{NO}_{2}$, peroxy nitrates, alkyl nitrates, $\mathrm{HNO}_{3}$, and total $\mathrm{NO}_{\mathrm{y}}$ in Houston, TX: implications for $\mathrm{O}_{3}$ photochemistry, PhD, University of California, Berkeley, Berkeley, 2004.

Rosen, R. S., Wood, E. C., Wooldridge, P. J., Thornton, J. A., Day, D. A., Kuster, W., Williams, E. J., Jobson, B. T., and Cohen, R. C.: Observations of total alkyl nitrates during Texas Air Quality Study 2000: Implications for $\mathrm{O}_{3}$ and alkyl nitrate photochemistry, J. Geophys. Res.-Atmos., 109, D07303, doi:10.1029/2003JD004227, 2004.

Rubio, M. A., Oyola, P., Gramsch, E., Lissi, E., Pizarro, J., and Villena, G.: Ozone and peroxyacetylnitrate in downtown Santiago, Chile, Atmos. Environ., 38, 4931-4939, 2004.

Schade, G. W., Dreyfus, G. B., and Goldstein, A. H.: Atmospheric methyl tertiary butyl ether (MTBE) at a rural mountain site in California, J. Environ. Quality, 31, 1088-1094, 2002.

Sehested, J., Christensen, L. K., Nielsen, O. J., Bilde, M., Wallington, T. J., Schneider, W. F., Orlando, J. J., and Tyndall, G. S.: Atmospheric chemistry of acetone: Kinetic study of the $\mathrm{CH}_{3} \mathrm{C}(\mathrm{O}) \mathrm{CH}_{2} \mathrm{O}_{2}+\mathrm{NO} / \mathrm{NO}_{2}$ reactions and decomposition of $\mathrm{CH}_{3} \mathrm{C}(\mathrm{O}) \mathrm{CH}_{2} \mathrm{O}_{2} \mathrm{NO}_{2}$, Int. J. Chem. Kinetics, 30, 475-489, 1998.

Singh, H. B. and Hanst, P. L.: Peroxyacetyl Nitrate (PAN) in the Unpolluted Atmosphere - an Important Reservoir For NitrogenOxides, Geophys. Res. Lett., 8, 941-944, 1981.

Singh, H. B.: Reactive nitrogen in the troposphere, Environ. Sci. Technol., 21, 320-327, 1987.

Stephens, E. R., Hanst, P. L., Doerr, R. C., and Scott, W. E.: Reactions of Nitrogen Dioxide and Organic Compounds in Air, Industrial Eng. Chem., 48, 1498-1504, 1956.

Talukdar, R. K., Burkholder, J. B., Schmoltner, A. M., Roberts, J. M., Wilson, R. R., and Ravishankara, A. R.: Investigation of the Loss Processes For Peroxyacetyl Nitrate in the Atmosphere UV Photolysis and Reaction With OH, J. Geophys. Res.-Atmos., 100, 14 163-14 173, 1995.

Thornberry, T. and Abbatt, J. P. D.: Heterogeneous reaction of ozone with liquid unsaturated fatty acids: detailed kinetics and gas-phase product studies, Phys. Chem. Chem. Phys., 6, 84-93, 2004.

Thornton, J. A., Wooldridge, P. J., and Cohen, R. C.: Atmospheric $\mathrm{NO}_{2}$ : In situ laser-induced fluorescence detection at parts per trillion mixing ratios, Analytical Chem., 72, 528-539, 2000.

Thornton, J. A., Wooldridge, P. J., Cohen, R. C., Williams, E. J., Hereid, D., Fehsenfeld, F. C., Stutz, J., and Alicke, B.: Comparisons of in situ and long path measurements of $\mathrm{NO}_{2}$ in urban plumes, J. Geophys. Res.-Atmos., 108, 4496, doi:10.1029/2003JD003559, 2003.

Tyndall, G. S., Orlando, J. J., Wallington, T. J., and Hurley, M. D.: Products of the chlorine-atom and hydroxyl-radical-initiated oxidation of $\mathrm{CH}_{3} \mathrm{CN}$, J. Phys. Chem. A, 105, 5380-5384, 2001.

Tyndall, G. S., Apel, E., Williams, E., Flocke, F., Cohen, R. C., Gilge, S., Kim, S., Kim, S., Mills, G., O’Brien, J., Perring, A., Rappenglueck, B., Roberts, J., Schmitt, R., Swanson, A., Tanimoto, H., and Wooldridge, P. J.: PIE 2005: An intercomparison of measurement techniques for peroxynitrates (PANs), paper pre- 
sented at AGU Fall Meeting, EOS Transactions, San Francisco, 2005.

UCAR: TUV (Total Ultraviolet and Visible radiation model), edited, http://www.acd.ucar.edu/TUV/, 2002.

Vuorinen, T., Nerg, A. M., Vapaavuori, E., and Holopainen, J. K.: Emission of volatile organic compounds from two silver birch (Betula pendula Roth) clones grown under ambient and elevated $\mathrm{CO}_{2}$ and different $\mathrm{O}_{3}$ concentrations, Atmos. Environ., 39, 1185-1197, 2005.

Wallington, T. J., Schneider, W. F., Mogelberg, T. E., Nielsen, O. J., and Sehested, J.: Atmospheric Chemistry of FCOx Radicals Kinetic and Mechanistic Study of the $\mathrm{FCO}(\mathrm{O})_{2}+\mathrm{NO}_{2}$ Reaction, Int. J. Chem. Kinetics, 27, 391-402, 1995.
Wedel, A., Muller, K. P., Ratte, M., and Rudolph, J.: Measurements of volatile organic compounds (VOC) during POPCORN 1994: Applying a new on-line GC-MS-technique, J. Atmos. Chem., 31, 73-103, 1998.

Wildt, J., Kobel, K., Schuh-Thomas, G., and Heiden, A. C.: Emissions of oxygenated volatile organic compounds from plants part II: Emissions of saturated aldehydes, J. Atmos. Chem., 45, 173-196, 2003.

Williams, J., Roberts, J. M., Fehsenfeld, F. C., Bertman, S. B., Buhr, M. P., Goldan, P. D., Hubler, G., Kuster, W. C., Ryerson, T. B., Trainer, M., and Young, V.: Regional ozone from biogenic hydrocarbons deduced from airborne measurements of PAN, PPN, and MPAN, Geophys. Res. Lett., 24, 1099-1102, 1997. 